\title{
Maternal Protein Malnutrition: Current and Future Perspectives of Spirulina Supplementation in Neuroprotection
}

\section{OPEN ACCESS}

Edited by:

Adriana Ximenes-da-Silva, Federal University of Alagoas, Brazil

Reviewed by:

Nafisa M. Jadavii,

Carleton University, Canada

Munmun Chattopadhyay,

Texas Tech University Health Sciences

Center El Paso, United States

*Correspondence: Ishan K. Patro

ishanpatro@gmail.com

Specialty section:

This article was submitted to Neuroenergetics, Nutrition and Brain

Health,

a section of the journal

Frontiers in Neuroscience

Received: 25 July 2018 Accepted: 03 December 2018 Published: 18 December 2018

Citation:

Sinha S, Patro N and Patro IK (2018) Maternal Protein Malnutrition:

Current and Future Perspectives of Spirulina Supplementation

in Neuroprotection.

Front. Neurosci. 12:966. doi: 10.3389/fnins.2018.00966

\author{
Shrstha Sinha ${ }^{1,2}$, Nisha Patro ${ }^{1}$ and Ishan K. Patro ${ }^{1,2 *}$ \\ ${ }^{1}$ School of Studies in Neuroscience, Jiwaji University, Gwalior, India, ${ }^{2}$ School of Studies in Zoology, Jiwaji University, \\ Gwalior, India
}

Malnutrition has been widely recognized as a grave burden restricting the progress of underdeveloped and developing countries. Maternal, neonatal and postnatal nutritional immunity provides an effective approach to decrease the risk of malnutrition associated stress in adulthood. Particularly, maternal nutritional status is a critical contributor for determining the long-term health aspects of an offspring. Maternal malnutrition leads to increased risk of life, poor immune system, delayed motor development and cognitive dysfunction in the children. An effective immunomodulatory intervention using nutraceutical could be used to enhance immunity against infections. The immune system in early life possesses enormous dynamic capacity to manage both genetic and environment driven processes and can adapt to rapidly changing environmental exposures. These immunomodulatory stimuli or potent nutraceutical strategy can make use of early life plasticity to target pathways of immune ontogeny, which in turn could increase the immunity against infectious diseases arising from malnutrition. This review provides appreciable human and animal data showing enduring effects of protein deprivation on CNS development, oxidative stress and inflammation and associated behavioral and cognitive impairments. Relevant studies on nutritional supplementation and rehabilitation using Spirulina as a potent protein source and neuroprotectant against protein malnutrition (PMN) induced deleterious changes have also been discussed. However, there are many futuristic issues that need to be resolved for proper modulation of these therapeutic interventions to prevent malnutrition.

Keywords: protein malnutrition, fetal programming, oxidative stress, inflammation, nutritional supplementation, Spirulina, neuroprotectant

\section{INTRODUCTION}

Rapid industrialization and commercialization have changed our living standard and dietary habits. A proper nutrition provides a flexible infrastructure for the brain development which forms the basis of human growth and economic progress. The hunger level is measured globally as Global Hunger Index (GHI) by Welthungerhilfe and concern worldwide to evaluate the progression in hunger (Von Grebmer et al., 2018). 12.3\% of world's population is undernourished with 27.9\% stunted and $9.3 \%$ wasted children as reported by GHI, 2018. Every country in the world is facing 
a grave burden of malnutrition where South Asia and Africa is striving hard with under serious hunger category with GHI of 30.5 and 29.4, respectively. The mortality rate of children aged under five, category is $4.2 \%$. However, GHI score of almost all countries from 2000 to 2018 decreased substantially except Central African Republic which shows no advancement. India ranks 103 out of 119 countries assessed with a GHI score of 31.1 (serious category). Still today, $20-50 \%$ of the patients admitted in hospital are found to be malnourished (Kirkland et al., 2013) with poor recovery rate from illness (Marshall et al., 2014). In simple words, malnutrition is a condition of imbalanced or inadequate nutrient intake by a person. It includes undernutrition (wasting, stunting, and underweight), over-nutrition (overweight and obesity) and micronutrient related malnutrition (micronutrient deficiency or excess). Malnutrition is a serious health problem associated with the increased susceptibility to mortality and morbidity. It is now widely accepted as silent executioner. In this review, we use the term 'malnutrition' to refer simply to a deficiency of nutrition particularly protein. Developmental Origins of Health and Disease (DOHAD) hypothesis suggest the link between early life developmental patterns and late onset of diseases (Barker et al., 2002; Shih et al., 2004). Many epidemiological and experimental reports suggest that nutritional status during fetal development plays an important role in maintaining energy metabolism at later life (Silveira et al., 2007; McMillen et al., 2008). The nutritional status of the mother strongly affects the brain development and cognitive abilities in the offspring. All the members in a community are affected by maternal nutritional patterns, but children and infant are at the highest risk as they need more nutrition for growth and development. Similarly, pregnant and lactating women are at risk and the babies born will be more prone to any disease at later life. Maternal and infant malnutrition is found to be associated with behavioral and cognitive impairment throughout the childhood and adulthood that makes them more vulnerable to neuropsychiatric disorders (Naik et al., 2015). Several studies demonstrated that maternal malnutrition alters the fetal genome and increases the risk of neuropsychiatric disorders including depression, schizophrenia, aggression, hyperactivity and antisocial behavior (Duran et al., 2005; Galler et al., 2005). In addition, it also reduces the thickness of the visual cortex, parietal neocortex, dentate gyrus, CA3 and cerebellum (Noback and Eisenman, 1981; Díaz-Cintra et al., 1990; Ranade et al., 2012). The compromised physical development, impaired spatial learning and memory, compromised astrogenesis and oligodendrogenesis leading to hypo-myelination have all been reported in an intragenerational protein restriction rat model (Naik et al., 2015, 2017; Patro et al., 2018). Protein malnutrition (PMN) is also found to be associated with free radical overproduction, decreased antioxidant defense system (Feoli et al., 2006; Khare et al., 2014) and immune impairments that initiate a cascade of inflammatory reaction (Welsh et al., 1998; Yamada et al., 2016).

Despite the high prevalence of the serious consequences of maternal PMN, a very little information dealing with potent nutritional rehabilitation strategies against malnutrition is available. There is an urgent need of food or a food supplement which imparts both nutritional and medicinal benefits to the society. Such types of dietary supplements are called as nutraceuticals or functional foods. Nowadays, microalgae are gaining popularity as a dietary supplement because of low cost, high nutritional value and enormous health benefits. Spirulina contains significant amount of proteins, vitamins, beta-carotene, minerals, polysaccharides, glycolipids and sulfolipids (Campanella et al., 1999; Blinkova et al., 2001; Watanabe et al., 2002; Colla et al., 2004). Various bioactive peptides are now derived from Spirulina which can be used as efficient nutraceutical ingredients in novel food designing (Ovando et al., 2018). A large number of studies evidence the neuroprotective role of Spirulina in variety of diseases like ischemic brain damage, Parkinson's disease, LPS induced inflammation and rheumatoid arthritis (Bhat and Madyastha, 2001; Stromberg et al., 2005; Patro et al., 2011). Thus, dietary complementation with Spirulina could be a cost-effective way to enhance the balanced food security in a natural way. This review is focused on the effects of malnutrition on fetal programming, CNS development, oxidative stress, inflammation and various nutritional supplementation and rehabilitation strategies with special attention on neuroprotective role of Spirulina against PMN induced changes.

\section{MATERNAL NUTRITION AND FETAL PROGRAMMING}

The development of mammalian central nervous system is a complex process that begins in utero and continues throughout the adolescence and adulthood. It is tightly regulated by both genetic and environmental factors. The prenatal and postnatal environment affects the brain development, maturation and function both positively and negatively depending on the type of environmental stimuli (Kolb and Whishaw, 1998; Lenroot and Giedd, 2008). Several studies were conducted using different animal models, protocols, sources and types of enrichment to analyze how prenatal environmental enrichment (EE) affects the development of fetus (Kiyono et al., 1985; Mychasiuk et al., 2012; Rosenfeld and Weller, 2012). In most of the studies, EE is reported to exhibit beneficial effects on neuronal growth and maturation, neurocognitive abilities, cortical thickness, dendritic arborization, synaptic integrity, vascular inflammation, and neurogenesis (Nilsson et al., 1999; Olson et al., 2006; Reynolds et al., 2010; Simpson and Kelly, 2011; Mesa-Gresa et al., 2013; Caporali et al., 2014). Such favorable effects appears to be a common denominator for the remedial efficacy of an EE against experimental pathologies including trauma, cerebral ischemia, astroglial degeneration, and glioma growth (Passineau et al., 2001; Dahlqvist et al., 2004; Anastasía et al., 2009; Yuan et al., 2009; Cao et al., 2010; Jain et al., 2013; Rodriguez et al., 2013; Garofalo et al., 2015). Both the embryological and the postnatal development of the offsprings are governed by in utero environment (Barbazanges et al., 1996; O'donnell et al., 2009). An enriched in utero environment probably helps the fetus to survive in a specific environment as newborns are more prone to a variety of infections. Neonatal infection is a predominant cause of childhood mortality and morbidity causing $40 \%$ of mortality 
in under five age group (Liu et al., 2012; Bhutta and Black, 2013; Blencowe et al., 2013; Lawn et al., 2014).

Any adverse environmental condition imposed during the most vulnerable period of development (gestational and lactational period) affects the epigenetic status and also alter the covalent modifications of the DNA and histones of embryos, fetuses, and neonates (Reynolds and Caton, 2012; Wu et al., 2012). These changes may influence the complete life cycle of an offspring and may be transmitted from one generation to another and thus could result in the origin of 'fetal programming' or 'neonatal programming' concept (Barker and Clark, 1997; Ji et al., 2016). Imbalanced maternal nutrition often leads to the pathophysiological condition termed as intrauterine growth restriction (IUGR). It exerts detrimental effects on preweaning survival and developmental rate, growth rate, food intake, organ structure and function (Wu et al., 2006; Rekiel et al., 2014) and onset of diseases at adulthood and senility, including type2 diabetes, hypertension, hyperglycemia, and cardiovascular disease (Alberti et al., 2005; Longo et al., 2013; Langley-Evans, 2015). It also affects the transfer of nutrients and oxygen from pregnant mother to fetus, vascular growth and functional capacity of placenta (Wu et al., 2004; Leddy et al., 2008). Maternal stress or infection during the prenatal or perinatal period also alters the physiological and behavioral profile of the stress response progression in offspring. One important pathway for the transmission of prenatal stress is through the secretion of corticosterone from mother to fetus via placenta, a proximal symbol of the outer environment. Prenatal inhibition of maternal corticosterone secretion exerts no difference between progeny of stressed and non-stressed mothers, thus signifying a possible mechanism of maternal stress transmission via corticosterone (Barbazanges et al., 1996; Cicchetti, 2016). The placenta plays a key role in maternal nutrient transport to the fetus, thus placental abnormalities may inhibit the nutrient support to fetus. The nutrient supply depends on the size of placenta, morphology, blood flow and nutrient transporters (Fowden et al., 2006; Higgins et al., 2011). Thus, proper modulation of placental function either through gene expression or supplementation (nutrients or hormones) is necessary to fulfill the energy demands of growing fetus (Belkacemi et al., 2010). Both undernutrition and overnutrition contributes to the metabolic syndrome and chronic life-threatening diseases in adults (Boney et al., 2005; Leddy et al., 2008; Rkhzay-Jaf et al., 2012). To elucidate this, a number of studies have been conducted across the world using rat as a model organism to mimic the conditions of protein calorie malnutrition, total calorie undernutrition, maternal protein restriction and anemia (Ozanne and Hales, 2002; Armitage et al., 2004). Out of all these models, maternally protein deprived rat model is the most extensively studied model which involves the feeding of a low protein diet (5-8\% protein) to pregnant dams in comparison to dams fed with a control diet (20\% protein). The F1 progeny born from protein restricted mothers presented low birth weight and were more prone to cardiovascular diseases and psychiatric disorders (Fernandez-Twinn et al., 2003). Moreover, maternal over-nutrition before and during gestation also resulted in abnormal weight gain during pregnancy as compared to the normally nourished mothers which further increases with each successive pregnancy (Castro and Avina, 2002). Such anomalies further contribute to the progression of gestational diabetes along with long lasting negative health consequences for the infant (Ostlund et al., 2004). The excess protein supplementations to pregnant mothers also result in preterm delivery and enhanced perinatal mortality (Say et al., 2003). It is also observed that high fat diet during pregnancy decreases the mitochondrial copy number in kidney, thus changing the glucose homeostasis leading to a condition in parallel with mammalian metabolic syndrome counting endothelial dysfunction, hypertension, altered serum lipid status and adiposity (Armitage et al., 2005). Similarly, maternal glycemia also result in increased body weight and chances of diabetes in offspring (Franks et al., 2006).

\section{PROTEIN MALNUTRITION AND CNS DEVELOPMENT}

The proper placental development, fetus growth and all other changes occurring in mother's body during pregnancy necessitate amino acids for protein formation. Both mother and fetus are actually competing for this 'scarce resource.' Major proportions of the amino acids in the fetus are transported from the maternal circulation through active transport (Regnault et al., 2005a,b). Both placenta and fetal tissues are the disposal sites of amino acids present in the fetus, which is further involved in fetal amino acid metabolism (Brown et al., 2011). Thus, because of great involvement of amino acid in CNS functioning (amino acid as precursors of neurotransmitter, structural proteins, enzymes, peptide hormones), studies on the effect of PMN in developing CNS is gaining acclamation. Generally, casein content is modified in the diet to design protein restricted animal model. The protein deprived diet consists of $5-9 \%$ protein, while $16-25 \%$ protein is present in the normal diet.

Brain development is tightly regulated by both environmental and genetic factors. The period of rapid brain growth is considered as most critical period of development as brain is more vulnerable to any insult during this period. Any insult incurred during this period of brain development may result in long lasting negative effects on brain function, behavior and cognition. Nutrition is one of the most important epigenetic regulators that can affect brain function and behavior. Nutritional insults during pregnancy changes the epigenetic of the fetal genome and may leave a permanent devastating effect. The severity of the effects depends on the developmental timeline and magnitude of insult, i.e., earlier the insult, the more permanent the effects are. Vast literature indicate that malnutrition influences the cell count, synapse formation, dendritic arborization, cellular differentiation and proliferation, cell migration, growth factor synthesis and myelination and all these changes in turn result in impaired motor and cognitive functions (Georgieff, 2007; Prado and Dewey, 2014). Other studies also reported a reduction in dendritic basal number and processes, spine density, thickness of dendrites, somal size and neuronal loss following malnutrition (Salas and Nieto, 1974; Garcia-Ruiz et al., 1993; Lister et al., 2005). Such changes in malnourished animals may lead to permanent disturbances 
in dendritic arborization, architecture and synaptic efficiency (West and Kemper, 1976; Desmond and Levy, 1988). In utero protein deprivation also leads to reduced body and brain weight (Dickerson et al., 1967; Smart et al., 1973; Peeling and Smart, 1994). In nutshell, the nutritional inadequacies affect the neuroanatomy, neurochemistry, neurophysiology and neuropathology of the nervous system. A balanced nutrient supply which includes protein, iron, zinc, folate, choline, vitamin A and polyunsaturated fatty acids, governs brain function, behavior and cognitive development (Rao and Georgieff, 2001). Rats born to protein deprived mothers have shown increased arterial blood pressure and high cardiovascular sympathetic tone (Ozaki et al., 2001; Barros et al., 2015). It is observed that periconceptional and prenatal nutritional insult affects the postnatal brain maturational events (Morgane et al., 2002). Early life nutritional insult is also reported to be associated with enhanced risk for schizophrenia development (Brown and Susser, 2008; Bale et al., 2010). Hippocampus is adversely affected by early malnutrition. A significant reduction in the size of cells of the dentate gyrus, reduction in the degree of dendritic branching, and reduction in the number of granule cells is evident in hippocampus (Levitsky and Strupp, 1995).

Salas and Nieto (1974) reported that PMN also affects the size of cerebellum and dendrites of cortical pyramidal cells. Cell generation time is also increased in undernourished conditions (Deo et al., 1978). In cerebellar cortex, granule cells and basket cells per Purkinje neuron were reduced in number along with hypoplasia of glial cell following PMN (Clos et al., 1977). Severe lactational undernutrition is also reported to decrease the number of cells both in external germinal layer and internal granular layer (Barnes and Altman, 1973).

More recently, Gould et al. (2018) have hypothesized that maternal PMN before implantation can cause the adverse developmental programming leading to behavioral deficits and short-term memory loss. This was correlated with reduced neural stem cell and progenitor cell numbers through suppressed proliferation, defective neurosphere formation and increased apoptosis. Relevant to this, one more study has shown impaired acquisition and memory following maternal protein restriction during pregnancy and/or lactation. Such memory impairment has been closely associated with altered glucocorticoid production, reduced hippocampal mossy fiber area and decreased basal dendritic length (Reyes-Castro et al., 2018). Additionally, Gianatiempo et al. (2018) have shown that perinatal PMN alters the mother-offspring interaction which further disrupt the maternal behavior and delay the acquisition of developmental landmarks and neurological reflex development. These behavioral alterations were not restricted to F1 generation only but also transmitted to following generation. These recent reports have further strengthened the idea that PMN results in neurobehavioral and epigenetic alteration leading to growth restriction and hypertension (de Brito Alves and Costa-Silva, 2018).

Our group is also engaged in working on the intragenerational PMN model of rats, i.e., on pregestational, gestational, and lactational PMN model (8\% protein) which corresponds well with IUGR clinical conditions of poor socioeconomic group of human females. We have reported a compromised physical development (decreased body weight and brain weight), delayed neurological reflex development (cliff avoidance and negative geotaxis reflex), hyperactivity, poor neuromuscular strength, impaired spatial learning and memory and low anxiety in F1 progeny of low protein fed rats (Naik et al., 2015). All these observed behavioral and cognitive impairments are signature mark of neurological disorders including autism and schizophrenia. We have also assessed the astrocytic density and turnover number in LP-F1 progeny using standard immunohistochemical procedures and qRT-PCR assay. Expression of GFAP protein (astrocytic marker) was not evident until E18 in LP rats, whereas numerous stars shaped GFAP+ cells were reported in E18 HP brain which suggested delayed astrogenesis following PMN. The same trend was also recorded in A2B5 (glial restricted precursor) and BLBP (secondary radial glia) immunolabeling where LP brains showed reduced labeling which further indicated low progenitor pooling in the LP-F1 brain (Naik et al., 2017). We further investigated the oligodendrocyte genesis, differentiation, maturation and myelination through immunohistochemistry and quantitative PCR using the expression of myelin associated glycoproteins (MAG), proteolipid protein (PLP), myelin oligo glycoprotein (MOG) and platelet derived growth factor receptor $\alpha$ (PDGFR $\alpha)$ and found reduced expression of myelin proteins depicting impaired myelination and linked behavioral dysfunction following intragenerational protein restricted model (Patro et al., 2018). Our findings clearly demonstrated that the detrimental changes in astrogenesis and oligodendrogenesis were reflected in the neurobehavioral and cognitive outcome in the LP-F1 rats. These results thus support that the early life adversities are the main cause of later life impairments and neurodevelopmental dysfunctions (Anderson et al., 2003; Patro et al., 2013).

\section{OXIDATIVE STRESS IN PROTEIN MALNUTRITION}

Oxidative stress generally occurs due to an imbalance between free radical, i.e., pro-oxidant content (hydrogen peroxide, superoxide, hydroxyl radical, alkoxyl and peroxyl radicals) and anti-oxidant (both enzymatic and non-enzymatic) response system of body. This pro-oxidant/anti-oxidant balance is necessary for proper body functioning. Both free radical and mitochondrial theories of aging are the most widely accepted theories of aging which speculate that reactive oxygen species (ROS) alter mitochondrial function by interfering with the replication and transcription machinery of mitochondrial DNA (mtDNA) resulting in more ROS generation, which in turn damage mtDNA. In accordance with the above theories, an aged tissue presents more ROS production suggesting ROS as a critical contributor in aging (Sawada and Carlson, 1987; Sohal and Dubey, 1994; Hamilton et al., 2001; Capel et al., 2005). ROS is responsible for generating DNA lesions which causes genetic instability. The most dominant DNA lesion formed by ROS is 7,8dihydro-8-oxo-deoxyguanosine (8-oxo-dG) which causes G:C to T:A transversions (Grollman and Moriya, 1993; Dizdaroglu et al., 2002). These devastating outcomes of ROS production 
can be neutralized by enhancing antioxidant defense system. Numerous studies have shown the inverse relationship between oxidative stress and life span. The enhanced expression of catalase (CAT) and superoxide dismutase (SOD) exhibits extended life expectancy in Drosophila (Orr and Sohal, 1994). Consistently, decreased life span is also observed in those C. elegans which are more susceptible to oxidative stress (Larsen, 1993; Ishii et al., 2004) whereas, antioxidant mimetics (SOD/CAT) reverse these changes and enhances $C$. elegans life span (Melov et al., 2000). The increased oxidative stress is also known to promote autophagy in Alzheimer disease (AD), Parkinson disease (PD), amyotrophic lateral sclerosis (ALS), Huntington disease (HD) brain samples, suggesting the possible role of autophagy in the pathophysiology of these diseases (Hirai et al., 2001; Nixon et al., 2005; Rubinsztein et al., 2005; Cherra and Chu, 2008).

Golden and Ramdath (1987), proposed that free radical overproduction is involved in pathogenesis of kwashiorkor leading to haemolytic anemia. Increased oxidative and nitrosative stress is reported to be involved in neurological disorders like AD, PD, HD, and aging (Sies, 1985; Calabrese et al., 2003; Mariani et al., 2005; Valko et al., 2007). de Brito Alves et al. (2016) examined the association between maternal PMN induced hypertension and oxidative stress. They noticed that oxidative dysfunction and impaired antioxidant defense system in ventral medulla might contribute to progression of hypertension following maternal protein restriction. Another study by Verma et al. (2017) also reported increased serum malondialdehyde levels leading to oxidative stress in severe acute malnourished children as compared to control group. Prenatal and lactational PMN in rats is found to be associated with increased levels of thiobarbituric acid reactive substance (lipid peroxidation product) in the cerebellum and cerebral cortex and decreased CAT activity in the cerebellum (Feoli et al., 2006). Similarly, increased plasma malondialdehyde (by-product of lipid peroxidation), protein carbonyl (byproduct of protein oxidation) and decreased anti-oxidants (ascorbic acid, glutathione, SOD, ceruloplasmin) were reported in a study conducted over 193 malnourished children of age group 6 months to 5 years in Eastern Uttar Pradesh, India (Khare et al., 2014). Increased red cells SOD was also observed in malnourished children with kwashiorkor and marasmus (Rana et al., 1996; Ashour et al., 1999). However, majority of the studies showed reduced antioxidant activity following PMN (Sive et al., 1993; Houssaini et al., 1997).

In response to any oxidative stress, antioxidant level either decreases due to their depletion during scavenging of free radicals or increases to overcome the oxidative stress development and this shift further depends on multiple factors including type and source of oxidative stress, duration of exposure, toxicant concentration, intensity and model organism. These findings indicate that increased oxidative stress and compromised antioxidant defense system following PMN may be a risk factor for developing serious neurological and neurodegenerative disorder at later life.

\section{MALNUTRITION AND INFLAMMATION}

Insufficient dietary intake of nutrients is the leading cause of immunodeficiency worldwide. A synergistic relation exists between malnutrition and infection where nutritional inadequacy increases the risk to infection by impairing both innate and adaptive arms of immune response (Neumann et al., 2004). Infection also affects the nutritional status of an individual by reducing food intake and impairing nutrient absorption (Woodward, 1998; Solomons, 2007). The severity of infection depends on health status, type of infection and dietary intake. PMN is associated with immune impairments that initiate a cascade of inflammatory reaction (Welsh et al., 1998). Undernutrition is also considered as a pro-inflammatory state with increased expression of IL-6 (Dulger et al., 2002). However, PMN induced inflammatory response is still a controversial subject.

Some studies in malnourished children demonstrate a decreased expression of inflammatory markers while others report inflammatory response similar to the healthy children (Bondestam et al., 1988; Malave et al., 1998). Leptin (adipocyte derived cytokine) is considered as a central mediator between nutrition, neuroendocrine system and immunity (FernandezRiejos et al., 2010) and PMN has been reported to result in a decreased concentration of leptin, thus increasing the susceptibility to infection (Matarese, 2000). Compromised cellular components of immune response (IFN-Y, TNF- $\alpha$, nitric oxide) have also been reported following PMN. These components are crucial for protection against Mycobacterium tuberculosis (Chan et al., 1996). Breast feeding enhances the infant immunity and provides protection against gastrointestinal and respiratory infections (Chien and Howie, 2001). Epidemiological data favors the association between breast milk feeding and reduced risk of type 1 diabetes, asthma, eczema, rheumatoid arthritis, multiple sclerosis and bowel disease (Brandtzaeg, 2003; Hanson et al., 2003). It contains a variety of lymphocytes, macrophages, neutrophils, cytokines, chemokines, growth factors and long chain polyunsaturated fatty acids (PUFAs) which aid in promoting the neonatal immune system development. Primarily, inflammation is a defensive response against any infection or stress but its exaggerated response may exert negative consequences to the infants. Breast milk is rich in both proinflammatory (IL-1 $\beta$, IL-6, IL- 8 , and TNF- $\alpha$ ) and anti-inflammatory (IL-10) cytokines. The only limitation in understanding the complete association between breast milk components and infant immunity is the variation that exists amongst women and period of active lactation. Higher fat content is observed in the milk of malnourished women as compared to the well nourished women, although difference is not statistically significant between the two groups (Spring et al., 1985). Alternatively, decreased protein, lactalbumin and lactoferrin concentration is reported in severely malnourished mothers (Lonnerdal et al., 1976; Forsum and Lonnerdal, 1980), whereas high protein diet results in enhanced nitrogen contents of milk (Emery, 1978). The rats fed with a very low protein diet (VLPD) develop systemic inflammation and vascular calcification as revealed in a recent publication (Yamada et al., 2016). 
TABLE 1 | Protective effects of Spirulina against oxidative stress and neuroinflammation.

\begin{tabular}{|c|c|c|c|}
\hline Parameter & Test species & Main findings & Reference \\
\hline \multicolumn{4}{|c|}{ Protein malnutrition induced oxidative stress and neuroinflammation } \\
\hline \multirow[t]{5}{*}{ Oxidative stress } & Rats & $\begin{array}{l}\text { Increased CAT and decreased SOD activity in } \\
\text { marasmic-kwashiorkor rats }\end{array}$ & $\begin{array}{l}\text { Akinola et al., } \\
2010\end{array}$ \\
\hline & Human & $\begin{array}{l}\text { Increased lipid peroxidation product (MDA) and } \\
\text { decreased anti-oxidant level (GSH, Zn-SOD) }\end{array}$ & $\begin{array}{l}\text { Khare et al., } \\
2014\end{array}$ \\
\hline & Human & $\begin{array}{l}\text { Reduced blood levels of CAT, SOD, GSH, } \\
\text { vitamin C and increased MDA concentration }\end{array}$ & Aly et al., 2014 \\
\hline & Rats & $\begin{array}{l}\text { Increased MDA level, reduced SOD enzyme } \\
\text { activity and metabolic dysfunction }\end{array}$ & $\begin{array}{l}\text { Vega et al., } \\
2016\end{array}$ \\
\hline & Human & Increased serum MDA levels & $\begin{array}{l}\text { Verma et al., } \\
2017\end{array}$ \\
\hline \multirow[t]{5}{*}{ Neuroinflammation } & Mice & $\begin{array}{l}\text { Decreased serum protein levels and reduced } \\
\text { superoxide anion production }\end{array}$ & $\begin{array}{l}\text { Redmond } \\
\text { et al., } 1991\end{array}$ \\
\hline & Human & $\begin{array}{l}\text { Reduced anti-oxidant level (glutathione and } \\
\text { vitamin E) in kwashiorkor patients and } \\
\text { increased concentration of IL- } 6 \text { and soluble } \\
\text { receptor of TNF- } \alpha\end{array}$ & $\begin{array}{l}\text { Sauerwein } \\
\text { et al., } 1997\end{array}$ \\
\hline & Rats & $\begin{array}{l}\text { High circulating concentration of TNF- } \alpha \text {, } \\
\text { increased expression of TNF- } \alpha \text { mRNA in liver, } \\
\text { reduced phagocytic activity of neutrophils and } \\
\text { increased superoxide anion production }\end{array}$ & $\begin{array}{l}\text { Silva et al., } \\
2010\end{array}$ \\
\hline & Rats & $\begin{array}{l}\text { Increased serum TNF- } \alpha \text { and urinary } \\
\text { 8-hydroxydeoxyguanosine level }\end{array}$ & $\begin{array}{l}\text { Yamada et al., } \\
2016\end{array}$ \\
\hline & Human & $\begin{array}{l}\text { Increased serum levels of pro-inflammatory } \\
\text { cytokines and reduced serum levels of } \mathrm{Zn}, \mathrm{Ca} \text {, } \\
\text { and } \mathrm{Mg}\end{array}$ & $\begin{array}{l}\text { El-Maksoud } \\
\text { et al., } 2017\end{array}$ \\
\hline \multicolumn{4}{|c|}{ Anti-oxidant and anti-inflammatory activities of Spirulina } \\
\hline \multirow[t]{5}{*}{ Anti-oxidant activity } & Human & $\begin{array}{l}\text { Reduced plasma level of MDA and increased } \\
\text { SOD activity }\end{array}$ & Lu et al., 2006 \\
\hline & Rat & $\begin{array}{l}\text { Increased level of antioxidants (GSH, SOD and } \\
\text { CAT) }\end{array}$ & $\begin{array}{l}\text { Jeyaprakash } \\
\text { and } \\
\text { Chinnaswamy, } \\
2007\end{array}$ \\
\hline & Mice & $\begin{array}{l}\text { Decreased lipid peroxidation (LPO) level and } \\
\text { antioxidants concentration (SOD and CAT) were } \\
\text { restored to near normal level }\end{array}$ & $\begin{array}{l}\text { Sharma et al., } \\
2007\end{array}$ \\
\hline & Mice & $\begin{array}{l}\text { Reduced LPO level in hippocampus, striatum } \\
\text { and cortex, increased CAT and glutathione } \\
\text { peroxidase activity }\end{array}$ & $\begin{array}{l}\text { Hwang et al., } \\
2011\end{array}$ \\
\hline & Rat & $\begin{array}{l}\text { Reduced lipid peroxidation and decreased } \\
\text { percentage of DNA fragmentation }\end{array}$ & $\begin{array}{l}\text { Hassan et al., } \\
2012\end{array}$ \\
\hline \multirow[t]{5}{*}{ Anti-inflammatory activity } & Human & $\begin{array}{l}\text { Reduced plasma MDA level, decreased } \\
\text { LDL-cholesterol and IL-6 expression }\end{array}$ & Lee et al., 2008 \\
\hline & Mice & $\begin{array}{l}\text { Inhibited humoral and cell mediated immune } \\
\text { response and decreased TNF- } \alpha \text { production }\end{array}$ & $\begin{array}{l}\text { Rasool and } \\
\text { Sabina, } 2009\end{array}$ \\
\hline & Human & $\begin{array}{l}\text { Increased indoleamine 2,3-dioxygenase (IDO) } \\
\text { level and ameliorated senescence }\end{array}$ & $\begin{array}{l}\text { Selmi et al., } \\
2011\end{array}$ \\
\hline & Rat & Reduced expression of TNF- $\alpha, \mathrm{IL}-1 \beta$, and IL-6 & $\begin{array}{l}\text { Abdel-Daim } \\
\text { et al., } 2015\end{array}$ \\
\hline & Human & $\begin{array}{l}\text { Increased CD4 cell count and significant } \\
\text { reduction in viral load }\end{array}$ & $\begin{array}{l}\text { Ngo-Matip } \\
\text { et al., } 2015\end{array}$ \\
\hline
\end{tabular}

Proinflammatory cytokines in particular TNF- $\alpha$ and IL-6 are reported to affect child growth in chronic inflammatory disorders, which could be rescued when these cytokines are blocked, stressing the correlation of abnormal expression of these cytokines with stunted growth (Sederquist et al., 2014).
This was evident from a recently published report by ElMaksoud et al. (2017) demonstrating the increased serum levels of proinflammatory cytokines and C-reactive protein in nutritionally stunted Egyptian children. Thus, there is a possible link between the malnutrition and inflammation, although the 
exact mechanism by which early life protein deprivation governs neuroimmunity and also how it integrates with neuroendocrine system needs further attention.

\section{NUTRITIONAL SUPPLEMENTATION FOR PROTEIN MALNUTRITION}

Dietary supplements generally exert protective effects against diet related diseases (obesity, diabetes, cardiovascular disease, and osteoporosis). The successful implementation of nutritional therapies demands a suitable target (pregnant women and/or children), which needs to be properly monitored and supplemented at critical window of development. Diverse studies across the world have proven the positive health benefits of oral nutritional supplementation (ONS) in the subjects suffering from adult malnutrition (Baldwin and Weekes, 2012; Collins et al., 2012). These ONS are enriched in high quality nutrition. Recently it has been reported that ONS improves the muscular strength of leg among malnourished and sarcopenic older patients (Cramer et al., 2016). A number of nutritional interventions during pregnancy were designed and studied to prevent IUGR. Maternal folic acid supplementation either alone or in combination with other vitamins decreases the incidences of neural tube defects in the offspring (Rieder, 1994; Pitkin, 2007; Bhutta et al., 2013). Similarly, maternal intake of cod liver oil during gestational and lactational period is associated with higher intelligence as measured by higher mental processing composite source (Helland et al., 2003). Both oral and intravenous arginine administration in IUGR pregnancies lead to body weight gain in fetus (Sieroszerski et al., 2004; Xiao and Li, 2005). Intra-amniotic or maternal protein supplementation could be a possible way to direct fetal growth. However, only few studies have focused on how maternal intake of individual amino acid or protein affects the embryo-fetal development especially in terms of brain structure, function and behavior.

\section{SPIRULINA: A WONDER NUTRACEUTICAL}

Nowadays, commercial food sector is interested in food or food products with nutritional and medicinal benefits. These types of food products come under an umbrella term 'nutraceutical.' They are also called as functional foods, medical foods, nutritional supplements or designer foods. Out of a huge range of available nutrients, microalgae (particularly Chlorella and Spirulina) are gaining special attention as a food supplement due to its easy availability, rapid growth, low cost and high nutritive value. Spirulina is extensively studied for its anti-oxidant, antiinflammatory, anti-bacterial, anti-viral and immunomodulatory properties (Mallikarjun Gouda et al., 2015; Wu Q. et al., 2016; Finamore et al., 2017) along with its potent role in preventing IUGR related abnormalities as summarized in Table $\mathbf{1}$.

Spirulina is a progeny of first photosynthetic life form that was created by nature 3.6 billion years ago and belongs to the phylum Cyanobacteria. The name Spirulina is derived from a Latin word meaning tiny spiral. It is microscopic, photosynthetic, filamentous, spiral shaped and dark-blue in color due to the presence of pigment called phycocyanin. Surprisingly, it doubles its biomass in every 2-5 days and grows naturally in ponds of brackish or alkaline water. Very few microorganisms are capable of surviving in such extreme conditions in which Spirulina develops which in turn ensures crop hygiene. W.H.O designated it as 'Food of the Future' because of its high protein content and rapid growth. Moreover, it is also called as a 'Super food' or 'Wonder food' and various published scientific studies reveal how it boosts the immune system and improves health. It is approved in Russia as 'Medicine food' for treating radiation induced effects whereas, NASA considered it as a 'Best food' for space travel, as its small quantity contains a range of nutrients.

The most commonly used species of Spirulina are Spirulina platensis and Spirulina maxima. It has been used as a food for human consumption for centuries and consumed in many different countries such as Germany, Brazil, Spain, France, Canada, United States, Ireland, Philippines, Argentina, India, and Africa. The cell wall of Spirulina is devoid of cellulose and mainly composed of mucopolysaccharides, which makes it easily digested, assimilated and effective for the people suffering from intestinal malabsorption (older people and victims of kwashiorkor). It exhibits various positive biological activities including anti-viral, antibacterial, anti-fungal, antiparasitic, free radical scavenging (anti-oxidant) and antiarthritic effect. Our lab demonstrated the protective efficacy of Spirulina against collagen-induced arthritis in (CIA) rats. Various antioxidant constituents (phycocyanin, carotenoids, vitamins) present in Spirulina suppresses the physiological, histological and biochemical changes produced during CIA in rats (Kumar et al., 2009). Use of Spirulina three times a day in fish feed (Maylandia lombardoi) is reported to increase growth rate and seed production as compared to Spirulina intake once a day (Karadal et al., 2017). It is widely used in treating nutritional deficiencies, recovering from malnutrition, immune enhancement and in correcting iron anemia. It stimulates hematopoiesis especially erythropoiesis. It meets all international food quality and has applications in health foods and therapeutics. Its impressive protein content and rapid growth have attracted the attention of both researchers and industrialist. Thus, Spirulina supplementation during pregnancy and lactation may be of great potential value as it contains all hematopoietic nutrients that will ultimately benefit both mother and fetus.

\section{NUTRITIONAL COMPOSITION OF SPIRULINA}

Spirulina is one of the most potent sources of nutrition. The protein content of Spirulina varies between 60 and $70 \%$ of its dry weight. It also contains vitamins (vitamin B-12, beta carotene, vitamin E), various mineral substances (iron, calcium, phosphorus, magnesium, and trace minerals), essential 


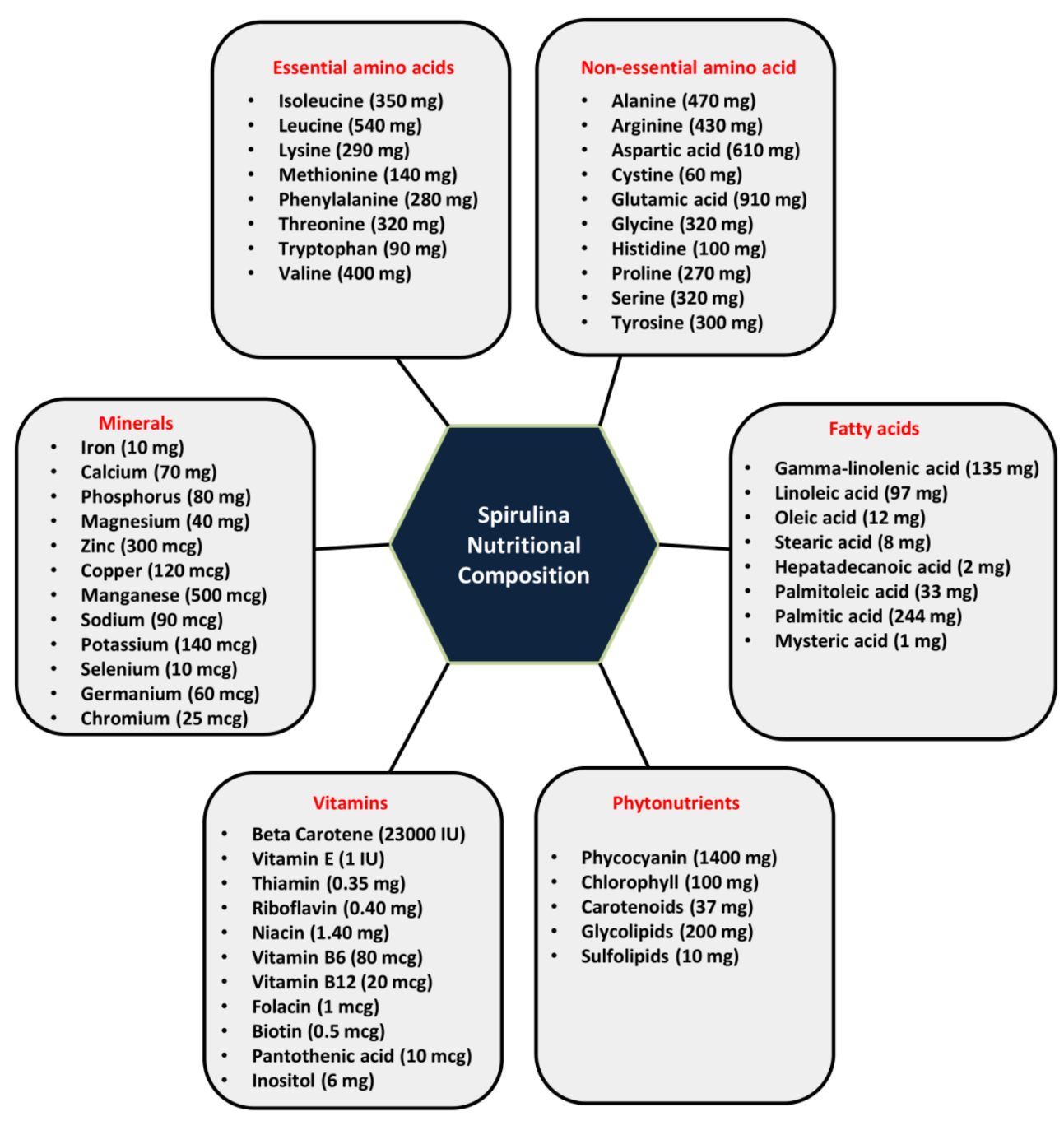

FIGURE 1 | Nutritional composition of Spirulina (serving size-10 gm of Spirulina): Spirulina is incredibly rich in proteins (60-70\%) and contains a wide range of essential amino acids, non-essential amino acids, vitamins, minerals, phytonutrients and fatty acids.

fatty acids (gamma-linoleic acid, palmitic acid, linoleic acid, oleic acid, etc.), polysaccharides (rhamnose and glycogen), glycolipids and sulfolipids, enzymes (SOD responsible for quenching free radicals) and various pigments like phycocyanin, chlorophyll, carotenoids (Campanella et al., 1999; Blinkova et al., 2001; Watanabe et al., 2002; Colla et al., 2004; Khan et al., 2005; Earthrise, 2006) as represented in Figure 1. Phycocyanobilin (phycobilin-protein complex) is an inhibitor of NADPH oxidase. This enzyme is involved in oxidative stress in various neurological disorders. Thus, Spirulina intake decreases the activity of NADPH oxidase and has therapeutic interventions in many vascular diseases, cancers, diabetes, neurodegenerative and inflammatory disorders (McCarty, 2007). It has been shown that carbohydrates present in Spirulina increases cell nucleus enzyme activity (particularly endonucleases) and DNA repair synthesis (Baojiang, 1994). It also positively influences both the humoral (antibodies and cytokines) and cell-mediated immunity ( $\mathrm{T}$ cell and macrophages). Downregulation of inflammatory and oxidative stress markers is observed in rats with Spirulina rich diets both in aging and neurodegenerative disorders making it more suitable as a natural drug for the treatment of neurological disorders.

\section{SPIRULINA AS THERAPEUTIC INTERVENTION AGAINST INFLAMMATION AND OXIDATIVE STRESS IN AGING AND NEURODEGENERATIVE CONDITIONS}

The predominant factors responsible for aging and neurodegeneration are inflammation and oxidative stress. There is a decline in the normal antioxidant and anti-inflammatory defense mechanisms in both aging and neurodegeneration that 
makes the brain more susceptible to the deleterious effects of oxidative stress (Finkel and Holbrook, 2000). There are considerably strong evidences elucidating that most neurological disorders (AD, PD, HD, ALS, inflammatory injuries, and senility) are the result of oxidation and/or inflammation. Various nutraceuticals as well as pharmaceuticals have been extensively investigated for their anti-inflammatory and antioxidant potential. With respect to nutraceutical, several dietary supplementations (blueberries, spinach and Spirulina) have been reported to protect CNS by downregulating the markers of inflammation and oxidative stress and thus reducing neurological deficits. Spirulina consumption also improves life span with numerous health benefits, increases locomotor activity and reduces HSP70 (indicator of cellular stress) and Jun-N-terminal kinase signaling (JNK signaling involved in modulating the life span) in DJ-1 $\beta^{\Delta 93}$ flies (a Parkinson's disease model) in Drosophila melanogaster (Kumar et al., 2017). A myriad of studies demonstrate that this dietary supplementation increases cerebellar glutathione levels, reduces malondialdehyde levels, decreases pro-inflammatory cytokines and improves spatial and motor learning in senile rats (Bickford et al., 2000; Gemma et al., 2002).

Thus, although an immense literature is available specifying the widely documented use of Spirulina as a functional food, yielding health promoting properties and/or reducing the risk of disease (Wu Z. et al., 2016; Furmaniak et al., 2017) only a very few and discrete studies have focused to report the adverse effects of Spirulina. More recently, the genome and proteome analysis of Arthrospira platensis has clearly mentioned the absence of genes responsible for the synthesis of various toxins (Furmaniak et al., 2017), supporting the statement that Spirulina shows no toxicity, i.e., neither acute nor chronic, making it safe for the human use (Gutierrez-Salmean et al., 2015). However, the minor adverse effects of Spirulina, reported include headache, gastrointestinal discomforts, muscle pain and cramps, skin rashes, etc. (Iwasa et al., 2002; Mazokopakis et al., 2008; Marles et al., 2011). In one study, the Spirulina was reported to be a causative factor for acute rhabdomyolysis in a young human patient (Mazokopakis et al., 2008). Although we have not come across any more studies specifying the adverse effects of Spirulina, but keeping in view the increasing use of Spirulina as dietary supplement, more studies are warranted to focus this issue.

\section{SPIRULINA AS A NEUROPROTECTANT}

Phenotypic outcomes are generally governed by epigenetic processes suggesting a possible connection between food quality and neurological disorders. Neuroprotective effects of Spirulina are well evidenced in ischemic brain damage with progressive decline in TUNEL positive cells and caspase3 activity in the ischemic hemisphere (Wang et al., 2005). Brain ischemia or cerebral ischemia is a condition marked by the cerebral hypoxia that leads to the generation of free radicals, reactive oxygen or nitrogen species and energy crisis. Phycocyanin and phycocyanobilin present in the Spirulina have strong anti-cyclooxygenase- 2 and anti-oxidant activities that reduce peroxynitrite induced oxidative damage to DNA (Bhat and Madyastha, 2001). Further advances and intervention studies in omics technology may provide useful information in understanding the mechanism of microglia mediated neuroinflammation (Patro et al., 2016) and the possible role of nutritional approaches in regulating microglia aging ( $\mathrm{Wu} \mathrm{Z}$. et al., 2016).

Dietary supplementation with Spirulina in rat model of Parkinson's disease results in significant reduction in lesion volume and decreased microglial activation (Stromberg et al., 2005). Anti-inflammatory effects of Spirulina have also been investigated against LPS-induced inflammation in rodent model. LPS insult causes increased astrogliosis with prominent activation of GFAP in existing cells and decreased proliferation of neural progenitor cells (NPCs). However, diet supplemented with $0.1 \%$ Spirulina for 28 days before LPS administration prevents the LPS induced decrease in NPC proliferation and astrogliosis (Bachstetter et al., 2010). Researchers at University of Yaounda (Azabji-Kenfack et al., 2011) found that food supplementation with Spirulina for 12 weeks in malnourished adults infected with HIV stimulates weight gain and increase fat free mass as compared to soya beans. In addition, antiretroviral treatment (ART) along with Spirulina showed more beneficial effects than ART coupled to soyabeans (increased CD4 cell counts and decreased viral load in Spirulina group). Spirulina platensis was also found to suppress the peripheral sensitization, improve motor coordination and restore motor activity in collagen-induced arthritic rats by reducing NF-200 accumulation in spinal cord neurons suggesting a possible neuroprotective role of Spirulina for the treatment of rheumatoid arthritis (Patro et al., 2011). Spirulina also supports the viability of astrocytes (Kim et al., 2012). Interestingly, polycaprolactone Spirulina nanofiber mat (composite nanomedicine) was proved to be effective against CNS injury as it reduces the astrocyte activation which in turn, could reduce inflammation induced by astrogliosis. Neuroprotective role of Spirulina is also marked in alpha-synuclein model of Parkinson's disease, where increased expression of tyrosine hydroxylase $(\mathrm{TH})$ positive and NeuN positive cells was observed. Accordingly, reduced number of activated microglia was also reported as determined by the reduced OX6 (MHC-II) immunostaining (Pabon et al., 2012).

It is thus apparent that dietary complementation with Spirulina could be beneficial to the patients suffering from neurodegenerative disorders. It maintains proliferation, differentiation and migration of NPCs which may lead to improved brain functioning and body health. The elevated response of human stem cells in terms of proliferation potential was also reported in Spirulina fed group. In normal conditions, CX3CL1 and CX3CR1 are expressed at high levels in brain, but as age advances their expression decreases. Spirulina intake shows the increased expression of CX3CR1, suggesting a possible mechanism of action in neuroprotection (Pabon, 2011). Generally, non-steroidal anti-inflammatory drugs act by suppressing the immune activation but Arthrospira enhances both the innate and adaptive immunity thereby 
increasing cellular and humoral adaptive immunity. There are now accumulating evidence that constituents of Spirulina have both anti-oxidant and anti-inflammatory activities that inhibits ROS formation and decreases the cytokine mediated neuroinflammation, thereby making it a suitable and effective therapeutic target for combating neurodegenerative disorders (Figure 2).

\section{NUTRITIONAL REHABILITATION USING SPIRULINA - SUPER FOOD TO FIGHT AGAINST MALNUTRITION}

Hunger can be either due to the non-availability of food or due to the lack of micronutrients. Inadequate food sources and improper nutritional awareness program in developing countries are the major causes of malnutrition. High protein content of Spirulina makes it a suitable adjunct to combat malnutrition. Both Spirulina platensis and Spirulina maxima have been extensively studied due to its high protein content, micronutrient composition, vitamins and minerals, easy and rapid reproducibility, inexpensive and non-toxic nature. Mass culture and utilization of Spirulina as a potent protein source against hunger, malnutrition and starvation was first explored and published by Rodulfo (1990). Many studies have shown a strong association between malnutrition and anemia thus suggesting malnutrition as a common cause of anemia in both children and elderly (Mitrache et al., 2001; Anticona and San Sebastian, 2014; Sahin et al., 2016).

Numerous studies have been conducted to test the efficacy of Spirulina supplementation in rodent model covering a range of variables including body growth, protein efficiency ratio (PER), hematological status and toxicity (Maranesi et al., 1984; Tranquille et al., 1994; Salazar et al., 1996; Narayan et al., 2005). Enhanced skeletal muscle proteins were also reported in Spirulina supplemented young rats (Voltarelli and de Mello, 2008). These animal based studies were further extended to clinical studies in human subject. In this context, various non-government organizations (NGO) and international organizations have chosen to work for reducing public health problems and prevention of malnutrition in developing countries. Azabji Kenfack and associates in 2011 examined the effect of daily Spirulina intake for 12 weeks on 56 malnourished HIV infected adult patients and concluded that Spirulina consumption effectively improved weight and body mass index (BMI) among undernourished HIV sufferers. Spirulina supplementation at a dose of $10 \mathrm{gm}$ per day was found to improve the nutritional status as well as to increase the corpuscular hemoglobin and hematocrit levels in malnourished children in Democratic Republic of the Congo (Matondo et al., 2016). Another research on 550 malnourished children showed the beneficial effects of Spirulina in combination with Misola (millet, coja, and peanut). This combination was proved to be more effective than Spirulina or Misola alone (Simpore et al., 2006). In addition to these, Spirulina platensis also exerts a positive impact against immunosenescence and anemia because of the presence of active components such as folic acids, vitamin B12, phycocyanin, essential amino acids and iron content, which in turn play central role in Erythropoiesis (Kapoor and Mehta, 1998; Mani et al., 2000; Khan et al., 2005; Selmi et al., 2011). Subsequently, one more study was conducted in Burkina Faso evaluating the effects of Spirulina consumption on 84 HIV positive and $86 \mathrm{HIV}$ negative anemic children, and the results indicated that $81.8 \%$ of HIV negative and $63.6 \%$ HIV positive children recovered from anemia, thus speculating potent role of Spirulina even in patients with compromised immune system (Simpore et al., 2005). Effectiveness of Spirulina against child malnutrition has also been reported in a study in Zambia, where 10 gm daily Spirulina consumption significantly improved HAZ (height-for-age-z) score in malnourished children (Masuda et al., 2014). From the above reports, it can be safely inferred that Spirulina supplementation can effectively combat the malnutrition.

\section{NEUROPROTECTIVE EFFECTS OF SPIRULINA CONSUMPTION DURING PREGNANCY AND/OR LACTATION}

Majority of the available studies have demonstrated the neuroprotective effects of Spirulina in adult animals. However, only few studies have been designed to investigate how maternal Spirulina supplementation would influence the developmental profile of an offspring. Spirulina enriched diet ( $0.1 \%$ Spirulina) to lactating mothers, 1 day prior to LPS treatment in offspring maintains the p38 and IL- $1 \beta$ levels thereby regulating neuroinflammation and antioxidant defense system in the offspring (Patil et al., 2018). Furthermore, Spirulina consumption by pregnant women in Dakar region is proved to be more effective than iron and folic acid (IFAC) supplementation in terms of weight gain and improved hemoglobinemia in the newborn (Niang et al., 2016). It has also been reported that supplementing pregnant hyperglycemic albino mice with Spirulina improves fertility rate, reproductive performance and reduces teratogenicity associated with diabetes (Pankaj, 2015). Furthermore, Banji et al. (2013) have reported that consumption of this edible alga from embryonic day (ED) 6 to postnatal day (PND) 15 reduces fluoride toxicity in developing brain, promotes antioxidant formation and minimizes the risk of neurodevelopmental disorders. These evidences mark the beneficial health effects of Spirulina in offsprings following Spirulina supplementation to pregnant mothers. However, the exact mechanism by which Spirulina supplementation during pregnancy imparts health benefits to the offsprings remains to be elucidated.

To the best of our knowledge, there is no complete study evaluating how Spirulina supplementation to malnourished pregnant and lactating mother would affect the oxidative functioning, inflammatory response and mental skills among children. Thus, enriching maternal environment with potent protein source (Spirulina) can be an effective way to reduce oxidative stress, neuroinflammation, behavioral and cognitive deficits induced by maternal PMN. This strategy of using 


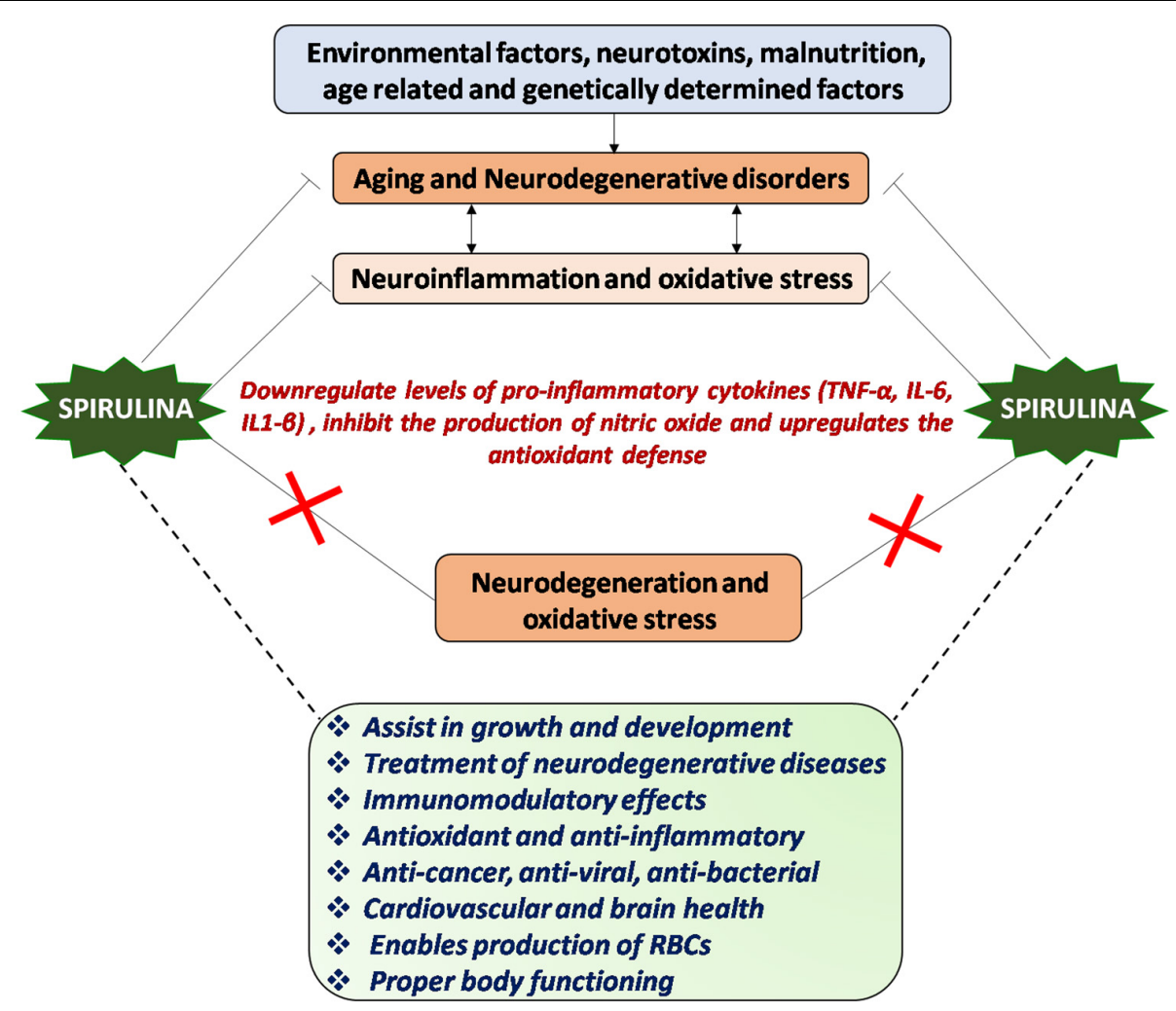

FIGURE 2 | Mechanism of action of Spirulina: Environmental and genetic factors regulate aging process and progression of neurological disorders, chiefly characterized by neuroinflammation and oxidative stress or vice-versa. Spirulina has both antioxidant and anti-inflammatory activities and downregulates the proinflammatory cytokines, which in turn might inhibit the neurodegeneration and oxidative stress thereby aids in maintaining proper brain and body health.

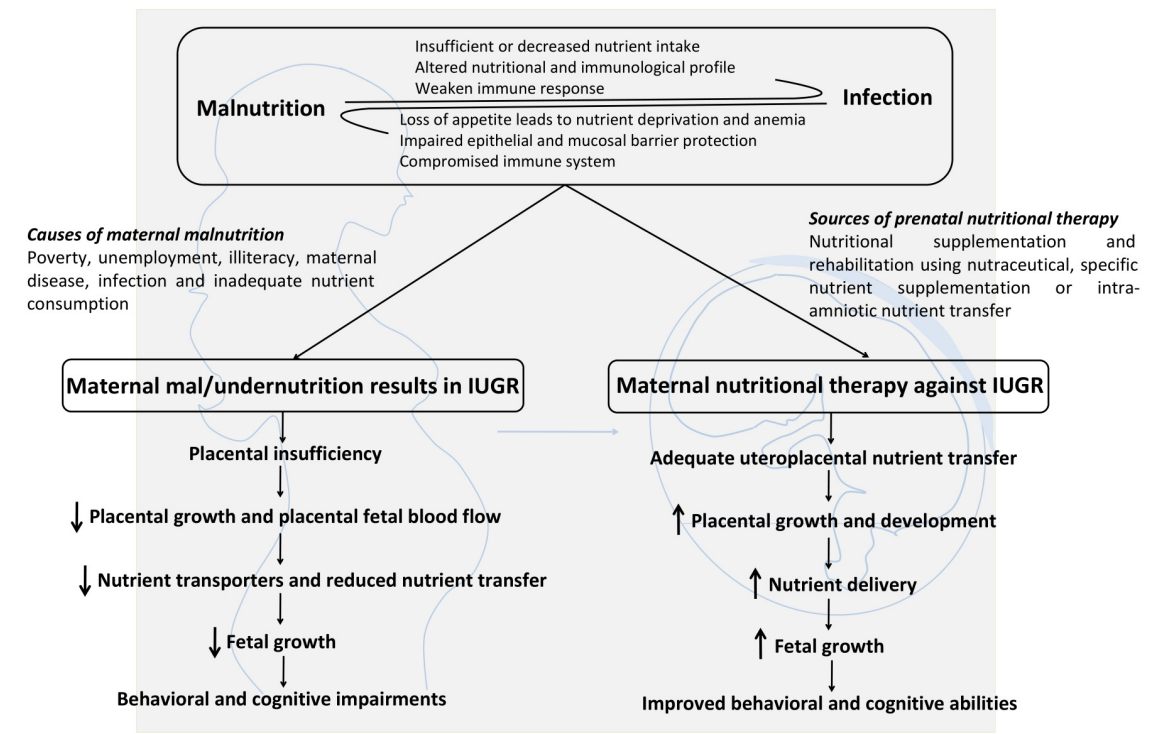

FIGURE 3 | Maternal malnutrition causes, consequences and possible nutritional supplementation strategies to treat IUGR: A synergistic relationship exists between malnutrition and infection. Maternal malnutrition results in decreased body growth and impaired behavioral and cognitive abilities. Prenatal nutritional therapy represents a promising approach to treat IUGR by enhancing uteroplacental nutrient transfer, placental growth and nutrient transport, fetal growth which ultimately results in improved behavioral and cognitive abilities. 
Spirulina during pregnancy and lactation period would be advantageous for treating abnormalities during IUGR pregnancy.

\section{CONCLUSION AND RECOMMENDATION}

Any environmental stress during critical periods of CNS development affects the developmental profile of an individual. Brain homeostasis and neuronal communication may be disturbed specifically in conditions of protein deprivation. Increased reactive oxygen and nitrogen species, impaired antioxidant defense system, altered glial cell physiology and inflammatory response are postulated to be the possible drivers in PMN induced neurocognitive decline. Diets enriched in foods with high ORAC could be used in reverting age and poor diet associated behavioral, cognitive and neurochemical impairments and maintaining cellular homeostasis. Spirulina contains a combination of nutrients ( $\beta$ carotene, vitamin B12, tocopherols, essential fatty acids, polysaccharides, glycolipids, sulfolipids and phycobiliprotein) which exerts more neuroprotective effects than single nutrient source. The present review has compiled the numerous studies conducted on Spirulina to establish its implications as a potent source of nutrition to combat against micronutrient deficiency, PMN and neurological disorders. The data discussed in this review suggests that exposure to malnutrition during critical developmental timeline where developmental plasticity is at peak, results in long lasting irreversible behavioral and cognitive abnormalities which further increases the risk of neurological disorders.

However, this review has certain limitations. More research is needed in understanding how Spirulina consumption affects neuron-glia communication? What is the exact molecular mechanism of Spirulina action? Is Spirulina supplementation enough for completely combating the detrimental effects of malnutrition? What are the important subcomponents of Spirulina necessary for making it as a neuroprotective agent and its dose response? What are the possible molecular targets while

\section{REFERENCES}

Abdel-Daim, M. M., Farouk, S. M., Madkour, F. F., and Azab, S. S. (2015). Anti-inflammatory and immunomodulatory effects of Spirulina platensis in comparison to Dunaliella salina in acetic acid-induced rat experimental colitis. Immunopharmacol. Immunotoxicol. 37, 126-139. doi: 10.3109/08923973.2014. 998368

Akinola, F. F., Oguntibeju, O. O., and Alabi, O. O. (2010). Effects of severe malnutrition on oxidative stress in Wistar rats. Sci. Res. Essays 5, 1145-1149.

Alberti, K. G. M., Zimmet, P., and Shaw, J. (2005). The metabolic syndrome- a new worldwide definition. Lancet 366, 1059-1062. doi: 10.1016/S0140-6736(05) 67402-8

Aly, G. S., Shaalan, A. H., Mattar, M. K., Ahmed, H. H., Zaki, M. E., and Abdallah, H. R. (2014). Oxidative stress status in nutritionally stuntedchildren. Gaz. Egypt Paediatr. Assoc. 62, 28-33. doi: 10.1016/j.epag.2014.02.003

Anastasía, A., Torre, L., De Erausquin, G. A., and Masco, D. H. (2009). Enriched environment protects the nigrostriatal dopaminergic system and induces astroglial reaction in the 6-OHDA rat model of Parkinson's disease. J. Neurochem. 109, 755-765. doi: 10.1111/j.1471-4159.2009.06001.x

Anderson, L. M., Shinn, C., Fullilove, M. T., Scrimshaw, S. C., Fielding, J. E., Normand, J., et al. (2003). The effectiveness of early childhood development considering pharmaco-therapeutic applications of Spirulina? Does it exert any effect on human epigenome? How Spirulina supplementation regulates placental function? All these questions need to be resolved in order to make Spirulina as an ideal natural drug with neuroprotective properties. Various nutritional inputs including nutritional supplementation, rehabilitation and therapy, nutritional education and specific nutrient supplementation (vitamins, mineral, and micronutrient) are necessary to overcome the detrimental effects of IUGR for better fetal growth and development (Figure 3). A combination of nutrition education and nutritional supplementation could exert more beneficial effects than any of the mentioned nutritional inputs alone. Inconsistency in research studies focusing on prenatal therapies and long term nutritional intervention programs are the major barriers to design effective strategies to fight malnutrition. Thus, a special attention should be given to animal studies involving both pre- and early postnatal nutritional supplementation along with intraamniotic nutrient transfer strategies to ameliorate fetal growth and metabolic functioning during IUGR pregnancy. Further advances and elucidation of the mechanism of action of dietary supplements and their effects on microbiota-gut brain axis will therefore open up new windows for therapeutic intervention against neurological disorders arising from malnutrition.

\section{AUTHOR CONTRIBUTIONS}

SS wrote this review with input from NP and IP.

\section{ACKNOWLEDGMENTS}

SS is a DST-INSPIRE (IF-150752) fellow. The authors are thankful to Department of Biotechnology for the extensive use of Bioinformatics Infrastructural Facility for shaping the review.

programs: a systematic review. Am. J. Prev. Med. 24, 32-46. doi: 10.1016/S07493797(02)00655-4

Anticona, C., and San Sebastian, M. (2014). Anemia and malnutrition in indigenous children and adolescents of the Peruvian Amazon in a context of lead exposure: a cross-sectional study. Glob. Health Act. 7:22888. doi: 10.3402/ gha.v7.22888

Armitage, J. A., Khan, I. Y., Taylor, P. D., Nathanielsz, P. W., and Poston, L. (2004). Developmental programming of the metabolic syndrome by maternal nutritional imbalance: how strong is the evidence from experimental models in mammals? J. Physiol. 561, 355-377. doi: 10.1113/jphysiol.2004.072009

Armitage, J. A., Taylor, P. D., and Poston, L. (2005). Experimental models of developmental programming: consequences of exposure to an energy rich diet during development. J. Physiol. 565, 3-8. doi: 10.1113/jphysiol.2004.079756

Ashour, M. N., Salem, S. I., El-Gadban, H. M., Elwan, N. M., and Basu, T. K. (1999). Antioxidant status in children with protein-energy malnutrition (PEM) living in Cairo. Egpt. Eur. J. Clin. Nutr. 53:669. doi: 10.1038/sj.ejcn.1600830

Azabji-Kenfack, M., Dikosso, S. E., Loni, E. G., Onana, E. A., Sobngwi, E., Gbaguidi, E., et al. (2011). Potential of Spirulina platensis as a nutritional supplement in malnourished HIV-infected adults in Sub-Saharan Africa: a randomised, single-blind study. Nutr. Metab. Insights 4:NMI-S5862. doi: 10. 4137/NMI.S5862 
Bachstetter, A. D., Jernberg, J., Schlunk, A., Vila, J. L., Hudson, C., Cole, M. J., et al. (2010). Spirulina promotes stem cell genesis and protects against LPS induced declines in neural stem cell proliferation. PLoS One 5:10496. doi: 10. 1371/journal.pone.0010496

Baldwin, C., and Weekes, C. E. (2012). Dietary counselling with or without oral nutritional supplements in the management of malnourished patients: a systematic review and meta-analysis of randomised controlled trials. J. Hum. Nutr. Diet 25, 411-426. doi: 10.1111/j.1365-277X.2012.01264.x

Bale, T. L., Baram, T. Z., Brown, A. S., Goldstein, J. M., Insel, T. R., McCarthy, M. M., et al. (2010). Early life programming and neurodevelopmental disorders. Biol. Psychiat. 68, 314-319. doi: 10.1016/j.biopsych.2010.05.028

Banji, D., Banji, O. J., Pratusha, N. G., and Annamalai, A. R. (2013). Investigation on the role of Spirulina platensis in ameliorating behavioural changes, thyroid dysfunction and oxidative stress in offspring of pregnant rats exposed to fluoride. Food Chem. 140, 321-331. doi: 10.1016/j.foodchem.2013.02.076

Baojiang, G. (1994). "Study on effect and mechanism of polysaccharides of Spirulina on body immune function improvement," in Proceedings of the Second Asia Pacific Conference on Algal Biotech (Kula Lumpur: University of Malaysia), 33-38.

Barbazanges, A., Piazza, P. V., Le Moal, M., and Maccari, S. (1996). Maternal glucocorticoid secretion mediates long-term effects of prenatal stress. J. Neurosci. 16, 3943-3949. doi: 10.1523/JNEUROSCI.16-12-03943

Barker, D. J., Eriksson, J. G., Forsén, T., and Osmond, C. (2002). Fetal origins of adult disease: strength of effects and biological basis. Int. J. Epidemiol. 31, 1235-1239. doi: 10.1093/ije/31.6.1235

Barker, D. J. P., and Clark, P. M. (1997). Fetal undernutrition and disease in later life. Rev. Reprod. 2, 105-112. doi: 10.1530/ror.0.0020105

Barnes, D., and Altman, J. (1973). Effects of different schedules of early undernutrition on the preweaning growth of the rat cerebellum. Exp. Neurol. 38, 406-419. doi: 1 0.1016/0014-4886(73)90163-5

Barros, M. A. V., Alves, J. D. B., Nogueira, V. O., Wanderley, A. G., and Costa-Silva, J. H. (2015). Maternal low-protein diet induces changes in the cardiovascular autonomic modulation in male rat offspring. Nutr. Metab. Cardiovasc. Dis. 25, 123-130. doi: 10.1016/j.numecd.2014.07.011

Belkacemi, L., Nelson, D. M., Desai, M., and Ross, M. G. (2010). Maternal undernutrition influences placental-fetal development. Biol. Reprod. 83, 325331. doi: 10.1095/biolreprod.110.084517

Bhat, V. B., and Madyastha, K. M. (2001). Scavenging of peroxynitrite by phycocyanin and phycocyanobilin from Spirulina platensis: protection against oxidative damage to DNA. Biochem. Biophys. Res. Commun. 285, 262-266. doi: 10.1006/bbrc.2001.5195

Bhutta, Z. A., and Black, R. E. (2013). Global maternal, newborn, and child health-so near and yet so far. N. Engl. J. Med. 369, 2226-2235. doi: 10.1056/ NEJMra1111853

Bhutta, Z. A., Das, J. K., Rizvi, A., Gaffey, M. F., Walker, N., Horton, S., et al. (2013). Evidence-based interventions for improvement of maternal and child nutrition: what can be done and at what cost? Lancet 382, 452-477. doi: 10.1016/S01406736(13)60996-4

Bickford, P. C., Gould, T., Briederick, L., Chadman, K., Pollock, A., Young, D., et al. (2000). Antioxidant-rich diets improve cerebellar physiology and motor learning in aged rats. Brain Res. 866, 211-217. doi: 10.1016/S0006-8993(00) 02280-0

Blencowe, H., Cousens, S., Chou, D., Oestergaard, M., Say, L., Moller, A. B., et al. (2013). Born too soon: the global epidemiology of 15 million preterm births. Reprod. Health 10:S2. doi: 10.1186/1742-4755-10-S1-S2

Blinkova, L. P., Gorobets, O. B., and Baturo, A. P. (2001). Biological activity of Spirulina platensis (SP). Zh. Mikrobiol. Epidemiol. Immunobiol. 2, 114-118.

Bondestam, M., Foucard, T., and Gebre-Medhin, M. (1988). Serum albumin, retinol-binding protein, thyroxin-binding prealbumin and acute phase reactants as indicators of undernutrition in children with undue susceptibility to acute infections. Acta Paediatr. 77, 94-98. doi: 10.1111/j.1651-2227.1988. tb10605.x

Boney, C. M., Verma, A., Tucker, R., and Vohr, B. R. (2005). Metabolic syndrome in childhood: association with birth weight, maternal obesity, and gestational diabetes mellitus. Pediatrics 115, 290-296. doi: 10.1542/peds.2004-1808

Brandtzaeg, P. (2003). Mucosal immunity: integration between mother and the breast-fed infant. Vaccine 21, 3382-3388. doi: 10.1016/j.jpeds.2009.11.014
Brown, A. S., and Susser, E. S. (2008). Prenatal nutritional deficiency and risk of adult schizophrenia. Schizophr. Bull. 34, 1054-1063. doi: 10.1093/schbul/sbn096

Brown, L. D., Green, A. S., Limesand, S. W., and Rozance, P. J. (2011). Maternal amino acid supplementation for intrauterine growth restriction. Front. Biosci. 3:428. doi: $10.2741 / \mathrm{s} 162$

Calabrese, V., Scapagnini, G., Colombrita, C., Ravagna, A., Pennisi, G., Stella, A. G., et al. (2003). Redox regulation of heat shock protein expression in aging and neurodegenerative disorders associated with oxidative stress: a nutritional approach. Amino Acids 25, 437-444. doi: 10.1007/s00726-003-0048-2

Campanella, L., Crescentini, G., and Avino, P. (1999). Chemical composition and nutritional evaluation of some natural and commercial food products based on Spirulina. Analusis 27, 533-540. doi: 10.1051/analusis: 1999130

Cao, L., Liu, X., Lin, E. J. D., Wang, C., Choi, E. Y., Riban, V., et al. (2010). Environmental and genetic activation of a brain-adipocyte BDNF/leptin axis causes cancer remission and inhibition. Cell 142, 52-64. doi: 10.1016/j.cell.2010. 05.029

Capel, F., Rimbert, V., Lioger, D., Diot, A., Rousset, P., Mirand, P. P., et al. (2005). Due to reverse electron transfer, mitochondrial $\mathrm{H}_{2} \mathrm{O}_{2}$ release increases with age in human vastus lateralis muscle although oxidative capacity is preserved. Mech. Ageing Dev. 126, 505-511. doi: 10.1016/j.mad.2004.11.001

Caporali, P., Cutuli, D., Gelfo, F., Laricchiuta, D., Foti, F., and De Bartolo, P. (2014). Pre-reproductive maternal enrichment influences offspring developmental trajectories: motor behavior and neurotrophin expression. Front. Behav. Neurosci. 8:195. doi: 10.3389/fnbeh.2014.00195

Castro, L. C., and Avina, R. L. (2002). Maternal obesity and pregnancy outcomes. Curr. Opin. Obstet. Gynecol. 14, 601-606. doi: 10.1097/01.gco.0000045486. 15021.C9

Chan, S. P., Birnbaum, J., Rao, M., and Steiner, P. (1996). Clinical manifestation and outcome of tuberculosis in children with acquired immunodeficiency syndrome. Pediatr. Infect. Dis. J. 15, 443-447. doi: 10.1097/00006454199605000-00012

Cherra, S. J. III, and Chu, C. T. (2008). Autophagy in neuroprotection and neurodegeneration: a question of balance. Future Neurol. 3, 309-323. doi: 10. 2217/14796708.3.3.309

Chien, P. F., and Howie, P. W. (2001). Breast milk and the risk of opportunistic infection in infancy in industrialized and non-industrialized settings. Adv. Nutr. Res. 10, 69-104. doi: 10.1007/978-1-4615-0661-4_4

Cicchetti, D. (2016). Developmental Psychopathology, Theory and Method. Hoboken, NJ: John Wiley and Sons. doi: 10.1002/9781119125556

Clos, J., Favre, C., Selme-Matrat, M., and Legrand, J. (1977). Effects of undernutrition on cell formation in the rat brain and specially on cellular composition of the cerebellum. Brain Res. 123, 13-26. doi: 10.1016/00068993(77)90640-0

Colla, L. M., Bertolin, T. E., and Costa, J. A. V. (2004). Fatty acids profile of Spirulina platensis grown under different temperatures and nitrogen concentrations. Z. Naturforsch. 59, 55-59. doi: 10.1515/znc-2004-1-212

Collins, P. F., Stratton, R. J., and Elia, M. (2012). Nutritional support in chronic obstructive pulmonary disease: a systematic review and meta-analysis. Am. J. Clin. Nutr. 95, 1385-1395. doi: 10.3945/ajcn.111.023499

Cramer, J. T., Cruz-Jentoft, A. J., Landi, F., Hickson, M., Zamboni, M., Pereira, S. L., et al. (2016). Impacts of high-protein oral nutritional supplements among malnourished men and women with sarcopenia: a multicenter, randomized, double-blinded, controlled trial. J. Am. Med. Dir. Assoc. 17, 1044-1055. doi: 10.1016/j.jamda.2016.08.009

Dahlqvist, P., Rönnbäck, A., Bergstrom, S. A., Söderström, I., and Olsson, T. (2004). Environmental enrichment reverses learning impairment in the Morris water maze after focal cerebral ischemia in rats. Eur. J. Neurosci. 19, 2288-2298. doi: 10.1111/j.0953-816X.2004.03248.x

de Brito Alves, J. L., and Costa-Silva, J. H. (2018). Maternal protein malnutrition induced-hypertension: new evidence about the autonomic and respiratory dysfunctions and epigenetic mechanisms. Clin. Exp. Pharmacol. Physiol. 45, 422-429. doi: 10.1111/1440-1681.12892

de Brito Alves, J. L., de Oliveira, J. M., Ferreira, D. J., Barros, M. A. D. V., Nogueira, V. O., Alves, D. S., et al. (2016). Maternal protein restriction induced-hypertension is associated to oxidative disruption at transcriptional and functional levels in the medulla oblongata. Clin. Exp. Pharmacol. Physiol. 43, 1177-1184. doi: 10.1111/1440-1681.12667 
Deo, K., Bijlani, V., and Deo, M. G. (1978). Effects of malnutrition on cell genesis and migration in developing brain in rats. Exp. Neurol. 62, 80-92. doi: 10.1016/ 0014-4886(78)90042-0

Desmond, N. L., and Levy, W. B. (1988). Synaptic interface surface area increases with long-term potentiation in the hippocampal dentate gyrus. Brain Res. 453, 308-314. doi: 10.1016/0006-8993(88)90171-0

Díaz-Cintra, S., Cintra, L., Ortega, A., Kemper, T., and Morgane, P. J. (1990). Effects of protein deprivation on pyramidal cells of the visual cortex in rats of three age groups. J. Comp. Neurol. 292, 117-126. doi: 10.1002/cne.902920108

Dickerson, J. W. T., Dobbing, J., and McCance, R. A. (1967). The effect of undernutrition on the postnatal development of the brain and cord in pigs. Proc. R. Soc. Lond. 166, 396-407. doi: 10.1098/rspb.1967.0003

Dizdaroglu, M., Jaruga, P., Birincioglu, M., and Rodriguez, H. (2002). Free radicalinduced damage to DNA: mechanisms and measurement1, 2. Free Radic. Biol. Med. 32, 1102-1115. doi: 10.1016/S0891-5849(02)00826-2

Dulger, H., Arik, M., Şekeroglu, M. R., Tarakçioððlu, M., Noyan, T., Cesur, Y., et al. (2002). Pro-inflammatory cytokines in Turkish children with protein-energy malnutrition. Mediat. Inflamm. 11, 363-365. doi: 10.1080/0962935021000051566

Duran, P., Cintra, L., Galler, J. R., and Tonkiss, J. (2005). Prenatal protein malnutrition induces a phase shift advance of the spontaneous locomotor rhythm and alters the rest/activity ratio in adult rats. Nutr. Neurosci. 8, 167-172. doi: 10.1080/10284150400026117

Earthrise (2006). "Product typical analysis. Earthrise farms Spirulina San Raphael, USA," in International Symposium on Cyanobacteria for Health, Science and Development, ed. L. Charpy (Marseille: Institut de Recherche Pour le Dévelopment), 104-108.

El-Maksoud, A. M. A., Khairy, S. A., Sharada, H. M., Abdalla, M. S., and Ahmed, N. F. (2017). Evaluation of pro-inflammatory cytokines in nutritionally stunted Egyptian children. Egpt. Paediatr. Assoc. Gaz. 65, 80-84. doi: 10.1016/j.epag. 2017.04.003

Emery, R. S. (1978). Feeding for increased milk protein 1. J. Dairy Sci. 61, 825-828. doi: 10.3168/jds.S0022-0302(78)83656-X

Feoli, A. M., Siqueira, I. R., Almeida, L., Tramontina, A. C., Vanzella, C., Sbaraini, S., et al. (2006). Effects of protein malnutrition on oxidative status in rat brain. J. Nutr. 22, 160-165. doi: 10.1016/j.nut.2005.06.007

Fernandez-Riejos, P., Najib, S., Santos-Alvarez, J., Martín-Romero, C., PérezPérez, A., González-Yanes, C., et al. (2010). Role of leptin in the activation of immune cells. Mediat. Inflamm. 2010:568343. doi: 10.1155/2010/568343

Fernandez-Twinn, D. S., Ozanne, S. E., Ekizoglou, S., Doherty, C., James, L., Gusterson, B., et al. (2003). The maternal endocrine environment in the lowprotein model of intra-uterine growth restriction. Br. J. Nutr. 90, 815-822. doi: 10.1079/BJN2003967

Finamore, A., Palmery, M., Bensehaila, S., and Peluso, I. (2017). Antioxidant, immunomodulating, and microbial-modulating activities of the sustainable and ecofriendly spirulina. Oxid. Med. Cell Longev. 2017:3247528. doi: 10.1155/2017/ 3247528

Finkel, T., and Holbrook, N. J. (2000). Oxidants, oxidative stress and the biology of ageing. Nature 408:239. doi: 10.1038/35041687

Forsum, E., and Lonnerdal, B. (1980). Effect of protein intake on protein and nitrogen composition of breast milk. Am. J. Clin. Nutr. 33, 1809-1813. doi: 10.1093/ajcn/33.8.1809

Fowden, A. L., Ward, J. W., Wooding, F. P. B., Forhead, A. J., and Constancia, M. (2006). Programming placental nutrient transport capacity. J. Physiol. 572, 5-15. doi: 10.1113/jphysiol.2005.104141

Franks, P. W., Looker, H. C., Kobes, S., Touger, L., Tataranni, P. A., and Hanson, R. L. (2006). Gestational glucose tolerance and risk of type 2 diabetes in young Pima Indian offspring. Diabetes Metab. Res. Rev. 55, 460-465. doi: 10.2337/ diabetes.55.02.06.db05-0823

Furmaniak, M. A., Misztak, A. E., Franczuk, M. D., Wilmotte, A., Waleron, M., and Waleron, K. F. (2017). Edible cyanobacterial genus Arthrospira: actual state of the art in cultivation methods, genetics, and application in medicine. Front. Microbiol. 8:2541. doi: 10.3389/fmicb.2017. 02541

Galler, J. R., Waber, D., Harrison, R., and Ramsey, F. (2005). Behavioral effects of childhood malnutrition. Am. J. Psychiatry. 162:760-b. doi: 10.1176/appi.ajp.162. 9.1760-b
Garcia-Ruiz, M., Díaz-Cintra, S., Cintra, L., and Corkidi, G. (1993). Effect of protein malnutrition on CA3 hippocampal pyramidal cells in rats of three ages. Brain Res. 625, 203-212. doi: 10.1016/0006-8993(76)90223-7

Garofalo, S., D’Alessandro, G., Chece, G., Brau, F., Maggi, L., Rosa, A., et al. (2015). Enriched environment reduces glioma growth through immune and non-immune mechanisms in mice. Nat. Commun. 6:6623. doi: 10.1038/ ncomms7623

Gemma, C., Mesches, M. H., Sepesi, B., Choo, K., Holmes, D. B., and Bickford, P. C. et al. (2002). Diets enriched in foods with high antioxidant activity reverse age-induced decreases in cerebellar $\beta$-adrenergic function and increases in proinflammatory cytokines. J. Neurosci. 22, 6114-6120. doi: 10.1523/ JNEUROSCI.22-14-06114.2002

Georgieff, M. K. (2007). Nutrition and the developing brain: nutrient priorities and measurement. Am. J. Clin. Nutr. 85, 614S-620S. doi: 10.1093/ajcn/85.2.614S

Gianatiempo, O., Sonzogni, S. V., Fesser, E. A., Belluscio, L. M., Smucler, E., Sued, M. R., et al. (2018). Intergenerational transmission of maternal care deficiency and offspring development delay induced by perinatal protein malnutrition. Nutr. Neurosci. 18, 1-11. doi: 10.1080/1028415X.2018.15 09178

Golden, M. H., and Ramdath, D. (1987). Free radicals in the pathogenesis of kwashiorkor. Proc. Nutr. Soc. 46, 53-68. doi: 10.1079/PNS19870008

Gould, J. M., Smith, P. J., Airey, C. J., Mort, E. J., Airey, L. E., Warricker, F. D., et al. (2018). Mouse maternal protein restriction during preimplantation alone permanently alters brain neuron proportion and adult short-term memory. Proc. Natl. Acad. Sci. U.S.A. 115, 7398-7407. doi: 10.1073/pnas.172187 6115

Grollman, A. P., and Moriya, M. (1993). Mutagenesis by 8-oxoguanine: an enemy within. Trends Genet. 9, 246-249. doi: 10.1016/0168-9525(93)90089-Z

Gutierrez-Salmean, G., Fabila-Castillo, L., and Chamorro-Cevallos, G. (2015). Nutritionaland toxicological aspects of Spirulina (Arthrospira). Nutr. Hosp. 32, 34-40. doi: 10.3305/nh.2015.32.1.9001

Hamilton, M. L., Van Remmen, H., Drake, J. A., Yang, H., Guo, Z. M., Kewitt, K., et al. (2001). Does oxidative damage to DNA increase with age? Proc. Natl. Acad. Sci. U.S.A. 98, 10469-10474. doi: 10.1073/pnas.171202698

Hanson, L. A., Korotkova, M., and Telemo, E. (2003). Breast-feeding, infant formulas, and the immune system. Ann. Allergy Asthma Immunol. 90, 59-63. doi: 10.1016/S1081-1206(10)61662-6

Hassan, A. M., Abdel-Aziem, S. H., and Abdel-Wahhab, M. A. (2012). Modulation of DNA damage and alteration of gene expression during aflatoxicosis via dietary supplementation of Spirulina (Arthrospira) and whey protein concentrate. Ecotoxicol. Environ. Saf. 79, 294-300. doi: 10.1016/j.ecoenv.2012. 01.017

Helland, I. B., Smith, L., Saarem, K., Saugstad, O. D., and Drevon, C. A. (2003). Maternal supplementation with very-long-chain n-3 fatty acids during pregnancy and lactation augments children's IQ at 4 years of age. Pediatrics 111, e39-e44. doi: 10.1542/peds.111.1.e39

Higgins, L., Greenwood, S. L., Wareing, M., Sibley, C. P., and Mills, T. A. (2011). Obesity and the placenta: a consideration of nutrient exchange mechanisms in relation to aberrant fetal growth. Placenta 32, 1-7. doi: 10.1016/j.placenta.2010. 09.019

Hirai, K., Aliev, G., Nunomura, A., Fujioka, H., Russell, R. L., Atwood, C. S., et al. (2001). Mitochondrial abnormalities in Alzheimer's disease. J. Neurosci. 21, 3017-3023. doi: 10.1523/JNEUROSCI.21-09-03017.2001

Houssaini, F. S., Iraqi, M. R., Arnaud, J., Richard, M. J., and Favier, A. (1997). Trace elements and protein-calorie malnutrition in the FES area (Morocco). Biomed. Pharmacother. 51, 349-351. doi: 10.1016/S0753-3322(97)88054-7

Hwang, J. H., Lee, I. T., Jeng, K. C., Wang, M. F., Hou, R. C. W., $\mathrm{Wu}$, S. M., et al. (2011). Spirulina prevents memory dysfunction, reduces oxidative stress damage and augments antioxidant activity in senescenceaccelerated mice. J. Nutr. Sci. Vitaminol. 57, 186-191. doi: 10.3177/jnsv. 57.186

Ishii, N., Senoo-Matsuda, N., Miyake, K., Yasuda, K., Ishii, T., and Hartman, P. S. (2004). Coenzyme Q 10 can prolong C. elegans lifespan by lowering oxidative stress. Mech. Ageing Dev. 125, 41-46. doi: 10.1016/j.mad.2003.10.002

Iwasa, M., Yamamoto, M., Tanaka, Y., Kaito, M., and Adachi, Y. (2002). Spirulinaassociated hepatotoxicity. Am. J. Gastroenterol. 97:3212. doi: 10.1111/j.15720241.2002.07145.x 
Jain, V., Baitharu, I., Prasad, D., and Ilavazhagan, G. (2013). Enriched environment prevents hypobaric hypoxia induced memory impairment and neurodegeneration: role of BDNF/PI3K/GSK3 $\beta$ pathway coupled with CREB activation. PLoS One 8:e62235. doi: 10.1371/journal.pone.006 2235

Jeyaprakash, K., and Chinnaswamy, P. (2007). Antioxidant property of Spirulina and Liv-52 against lead induced toxicity in albino rats. J. Nat. Remed. 7, 80-85. doi: $10.18311 /$ jnr/2007/198

Ji, Y., Wu, Z., Dai, Z., Sun, K., Wang, J., and Wu, G. (2016). Nutritional epigenetics with a focus on amino acids: implications for the development and treatment of metabolic syndrome. J. Nutr. Biochem. 27, 1-8. doi: 10.1016/j.jnutbio.2015.08 .003

Kapoor, R., and Mehta, U. (1998). Supplementary effect of spirulina on hematological status of rats during pregnancy and lactation. Plant Foods Hum. Nutr. 52, 315-324. doi: 10.1023/A:1008027408919

Karadal, O., Guroy, D., and Turkmen, G. (2017). Effects of feeding frequency and Spirulina on growth performance, skin coloration and seed production on kenyi cichlids (Maylandia lombardoi). Aquacult. Int. 25, 121-134. doi: 10.1007/ s10499-016-0017-x

Khan, Z., Bhadouria, P., and Bisen, P. S. (2005). Nutritional and therapeutic potential of Spirulina. Curr. Pharm. Biotechnol. 6, 373-379. doi: 10.2174/ 138920105774370607

Khare, M., Mohanty, C., Das, B. K., Jyoti, A., Mukhopadhyay, B., and Mishra, S. P. (2014). Free radicals and antioxidant status in protein energy malnutrition. Int. J. Pediatr. 2014:254396. doi: 10.1155/2014/254396

Kim, S. H., Shin, C., Min, S. K., Jung, S. M., and Shin, H. S. (2012). In vitro evaluation of the effects of electrospun PCL nanofiber mats containing the microalgae Spirulina (Arthrospira) extract on primary astrocytes. Colloids Surf. B Biointerfaces 90, 113-118. doi: 10.1016/j.colsurfb.2011.10.004

Kirkland, L. L., Kashiwagi, D. T., Brantley, S., Scheurer, D., and Varkey, P. (2013). Nutrition in the hospitalized patient. J. Hosp. Med. 8, 52-58. doi: 10.1002/jhm. 1969

Kiyono, S., Seo, M. L., Shibagaki, M., and Inouye, M. (1985). Facilitative effects of maternal environmental enrichment on maze learning in rat offspring. Physiol. Behav. 34, 431-435. doi: 10.1016/0031-9384(85)90207-0

Kolb, B., and Whishaw, I. Q. (1998). Brain plasticity and behavior. Annu. Rev. Psychol. 49, 43-64. doi: 10.1146/annurev.psych.49.1.43

Kumar, A., Christian, P. K., Panchal, K., Guruprasad, B. R., and Tiwari, A. K. (2017). Supplementation of Spirulina (Arthrospira platensis) improves lifespan and locomotor activity in paraquat-sensitive DJ-1 $\beta^{\Delta} 93$ flies, a parkinson's disease model in Drosophila melanogaster. J. Diet. Suppl. 14, 573-588. doi: 10.1080/19390211.2016.1275917

Kumar, N., Singh, S., Patro, N., and Patro, I. (2009). Evaluation of protective efficacy of Spirulina platensis against collagen-induced arthritis in rats. Inflammopharmacology 17, 181-190. doi: 10.1007/s10787-009-0004-1

Langley-Evans, S. C. (2015). Nutrition in early life and the programming of adult disease: a review. J. Hum. Nutr. 28, 1-14. doi: 10.1111/jhn.12212

Larsen, P. L. (1993). Aging and resistance to oxidative damage in Caenorhabditis elegans. Proc. Natl. Acad. Sci. U.S.A. 90, 8905-8909. doi: 10.1073/pnas.90.19. 8905

Lawn, J. E., Blencowe, H., Oza, S., You, D., Lee, A. C., Waiswa, P., et al. (2014). Every newborn: progress, priorities, and potential beyond survival. Lancet 384, 189-205. doi: 10.1016/S0140-6736(14)60496-7

Leddy, M. A., Power, M. L., and Schulkin, J. (2008). The impact of maternal obesity on maternal and fetal health. Rev. Obstet. Gynecol. 1:170.

Lee, E. H., Park, J. E., Choi, Y. J., Huh, K. B., and Kim, W. Y. (2008). A randomized study to establish the effects of spirulina in type 2 diabetes mellitus patients. Nutr. Res. Pract. 2, 295-300. doi: 10.4162/nrp.2008.2.4.295

Lenroot, R. K., and Giedd, J. N. (2008). The changing impact of genes and environment on brain development during childhood and adolescence: initial findings from a neuroimaging study of pediatric twins. Dev. Psychopathol. 20, 1161-1175. doi: 10.1017/S095457940800 0552

Levitsky, D. A., and Strupp, B. J. (1995). Malnutrition and the brain: changing concepts, changing concerns. J. Nutr. 125, 2212S-2220S. doi: 10.1093/jn/125. suppl_8.2212S

Lister, J. P., Blatt, G. J., DeBassio, W. A., Kemper, T. L., Tonkiss, J., Galler, J. R., et al. (2005). Effect of prenatal protein malnutrition on numbers of neurons in the principal cell layers of the adult rat hippocampal formation. Hippocampus 15, 393-403. doi: 10.1002/hipo.20065

Liu, L., Johnson, H. L., Cousens, S., Perin, J., Scott, S., Lawn, J. E., et al. (2012). Global, regional, and national causes of child mortality: an updated systematic analysis for 2010 with time trends since 2000. Lancet 379, 2151-2161. doi: 10.1016/S0140-6736(12)60560-1

Longo, S., Bollani, L., Decembrino, L., Di Comite, A., Angelini, M., and Stronati, M. (2013). Short-term and long-term sequelae in intrauterine growth retardation (IUGR). J. Matern. Fetal Neonatal Med. 26, 222-225. doi: 10.3109/14767058. 2012.715006

Lonnerdal, B., Forsum, E., Gebre-Medhin, M., and Hambraeus, L. (1976). Breast milk composition in Ethiopian and Swedish mothers. II. Lactose, nitrogen, and protein contents. Am. J. Clin. Nutr. 29, 1134-1141. doi: 10.1093/ajcn/29.10. 1134

Lu, H. K., Hsieh, C. C., Hsu, J. J., Yang, Y. K., and Chou, H. N. (2006). Preventive effects of Spirulina platensis on skeletal muscle damage under exercise-induced oxidative stress. Eur. J. Appl. Physiol. 98:220. doi: 10.1007/s00421-006-0263-0

Malave, I., Vethencourt, M. A., Pirela, M., and Cordero, R. (1998). Serum levels of thyroxine-binding prealbumin, C-reactive protein and interleukin-6 in protein-energy undernourished children and normal controls without or with associated clinical infections. J. Trop. Pediatr. 44, 256-262. doi: 10.1093/tropej/44. 5.256

Mallikarjun Gouda, K. G., Kavitha, M. D., and Sarada, R. (2015). Antihyperglycemic, antioxidant and antimicrobial activities of the butanol extract from Spirulina platensis. J. Food Biochem. 39, 594-602. doi: $10.1111 /$ jfbc. 12164

Mani, U. V., Desai, S., and Iyer, U. (2000). Studies on the long-term effect of spirulina supplementation on serum lipid profile and glycated proteins in NIDDM patients. J. Diet. Suppl. 2, 25-32. doi: 10.1300/J133v02n03_03

Maranesi, M., Barzanti, V., Carenini, G., and Gentili, P. (1984). Nutritional studies on Spirulina maxima. Acta Vitaminol. Enzymol. 6, 295-304.

Mariani, E., Polidori, M. C., Cherubini, A., and Mecocci, P. (2005). Oxidative stress in brain aging, neurodegenerative and vascular diseases: an overview. J. Chromatogr. B 827, 65-75. doi: 10.1016/j.jchromb.2005. 04.023

Marles, R. J., Barrett, M. L., Barnes, J., Chavez, M. L., Gardiner, P., Ko, R., et al. (2011). United States pharmacopeia safety evaluation of Spirulina. Crit. Rev. Food Sci. Nutr. 51, 593-604. doi: 10.1080/10408391003721719

Marshall, S., Bauer, J., and Isenring, E. (2014). The consequences of malnutrition following discharge from rehabilitation to the community: a systematic review of current evidence in older adults. J. Hum. Nutr. Diet. 27, 133-141. doi: 10. $1111 /$ jhn. 12167

Masuda, K., Inoue, Y., Inoue, R., Nakamura, A., Chitundu, M., Murakami, J., et al. (2014). Spirulina Effectiveness Study on Child Malnutrition in Zambia. Brighton: Institute of Development studies, 49-56.

Matarese, G. (2000). Leptin and the immune system: how nutritional status influences the immune response. Eur. Cytokine Netw. 11, 7-14.

Matondo, F. K., Takaisi, K., Nkuadiolandu, A. B., Kazadi Lukusa, A., and Aloni, M. N. (2016). Spirulina supplements improved the nutritional status of undernourished children quickly and significantly: experience from kisantu, the Democratic Republic of the Congo. Int. J. Pediatr. 2016:1296414. doi: 10.1155/ 2016/1296414

Mazokopakis, E. E., Karefilakis, C. M., Tsartsalis, A. N., Milkas, A. N., and Ganotakis, E. S. (2008). Acute rhabdomyolysis caused by Spirulina (Arthrospira platensis). Phytomedicine 15, 525-527. doi: 10.1016/j.phymed.2008.03.003

McCarty, M. F. (2007). Clinical potential of Spirulina as a source of phycocyanobilin. J. Med. Food 10, 566-570. doi: 10.1089/jmf.2007.621

McMillen, I. C., MacLaughlin, S. M., Muhlhausler, B. S., Gentili, S., Duffield, J. L., and Morrison, J. L. (2008). Developmental origins of adult health and disease: the role of periconceptional and foetal nutrition. Basic Clin. Pharmacol. Toxicol. 102, 82-89. doi: 10.1111/j.1742-7843.2007.00188.x

Melov, S., Ravenscroft, J., Malik, S., Gill, M. S., Walker, D. W., Clayton, P. E., et al. (2000). Extension of life-span with superoxide dismutase/catalase mimetics. Science 289, 1567-1569. doi: 10.1126/science.289.5484.1567

Mesa-Gresa, P., Pérez-Martinez, A., and Redolat, R. (2013). Environmental enrichment improves novel object recognition and enhances agonistic behavior in male mice. Aggress. Behav. 39, 269-279. doi: 10.1002/ab.21481 
Mitrache, C., Passweg, J., Libura, J., Petrikkos, L., Seiler, W., Gratwohl, A., et al. (2001). Anemia: an indicator for malnutrition in the elderly. Ann. Hematol. 80, 295-298. doi: 10.1007/s002770100287

Morgane, P. J., Mokler, D. J., and Galler, J. R. (2002). Effects of prenatal protein malnutrition on the hippocampal formation. Neurosci. Biobehav. Rev. 26, 471483. doi: 10.1016/S0149-7634(02)00012-X

Mychasiuk, R., Zahir, S., Schmold, N., Ilnytskyy, S., Kovalchuk, O., and Gibb, R. (2012). Parental enrichment and offspring development: modifications to brain, behavior and the epigenome. Behav. Brain Res. 228, 294-298. doi: 10.1016/j.bbr. 2011.11.036

Naik, A. A., Patro, I. K., and Patro, N. (2015). Slow physical growth, delayed reflex ontogeny, and permanent behavioral as well as cognitive impairments in rats following intra-generational protein malnutrition. Front. Neurosci. 9:446. doi: 10.3389/fnins.2015.00446

Naik, A. A., Patro, N., Seth, P., and Patro, I. K. (2017). Intra-generational protein malnutrition impairs temporal astrogenesis in rat brain. Biol. Open 6, 931-942. doi: 10.1242/bio.023432

Narayan, M. S., Manoj, G. P., Vatchravelu, K., Bhagyalakshmi, N., and Mahadevaswamy, M. (2005). Utilization of glycerol as carbon source on the growth, pigment and lipid production in Spirulina platensis. Int. J. Food Sci. Nutr. 56, 521-528. doi: 10.1080/09637480500410085

Neumann, C. G., Gewa, C., and Bwibo, N. O. (2004). Child nutrition in developing countries. Pediatr. Ann. 33, 658-674. doi: 10.3928/0090-4481-20041001-09

Ngo-Matip, M. E., Pieme, C. A., Azabji-Kenfack, M., Moukette, B. M., Korosky, E., Stefanini, P., et al. (2015). Impact of daily supplementation of Spirulina platensis on the immune system of naïve HIV-1 patients in Cameroon: a 12-months single blind, randomized, multicenter trial. Nutr. J. 14:70. doi: 10.1186/s12937015-0058-4

Niang, K., Ndiaye, P., Faye, A., Tine, J. A. D., Diongue, F. B., Camara, M. D., et al. (2016). Spirulina supplementation in pregnant women in the dakar region (senegal). Open J. Obstet. Gynecol. 7:147. doi: 10.4236/ojog.2017.71016

Nilsson, M., Perfilieva, E., Johansson, U., Orwar, O., and Eriksson, P. S. (1999). Enriched environment increases neurogenesis in the adult rat dentate gyrus and improves spatial memory. J. Neurobiol. 39, 569-578. doi: 10.1002/(SICI)10974695(19990615)39:4<569::AID-NEU10>3.0.CO;2-F

Nixon, R. A., Wegiel, J., Kumar, A., Yu, W. H., Peterhoff, C., Cataldo, A., et al. (2005). Extensive involvement of autophagy in Alzheimer disease: an immunoelectron microscopy study. J. Neuropath. Exp. Neur. 64, 113-122. doi: 10.1093/ jnen/64.2.113

Noback, C. R., and Eisenman, L. M. (1981). Some effects of protein-calorie undernutrition on the developing central nervous system of the rat. Anat. Rec. 201, 67-73. doi: 10.1002/ar.1092010109

O'donnell, K., O'connor, T. G., and Glover, V. (2009). Prenatal stress and neurodevelopment of the child: focus on the HPA axis and role of the placenta. Dev. Neurosci. 31, 285-292. doi: 10.1159/000216539

Olson, A. K., Eadie, B. D., Ernst, C., and Christie, B. R. (2006). Environmental enrichment and voluntary exercise massively increase neurogenesis in the adult hippocampus via dissociable pathways. Hippocampus 16, 250-260. doi: 10.1002/ hipo. 20157

Orr, W. C., and Sohal, R. S. (1994). Extension of life-span by overexpression of superoxide dismutase and catalase in Drosophila melanogaster. Science 263, 1128-1130. doi: 10.1126/science. 8108730

Ostlund, I., Haglund, B., and Hanson, U. (2004). Gestational diabetes and preeclampsia. Eur. J. Obstet. Gynecol. Reprod. Biol. 113, 12-16. doi: 10.1016/j. ejogrb.2003.07.001

Ovando, C. A., Carvalho, J. C. D., Vinícius de Melo Pereira, G., Jacques, P., Soccol, V. T., and Soccol, C. R. (2018). Functional properties and health benefits of bioactive peptides derived from Spirulina: a review. Food. Rev. Int. 34, 34-51. doi: 10.1080/87559129.2016.1210632

Ozaki, T., Nishina, H., Hanson, M. A., and Poston, L. (2001). Dietary restriction in pregnant rats causes gender-related hypertension and vascular dysfunction in offspring. J. Physiol. 530, 141-152. doi: 10.1111/j.1469-7793.2001.0141m.x

Ozanne, S. E., and Hales, C. N. (2002). Early programming of glucose-insulin metabolism. Trends Endocrinol. Metab. 13, 368-373. doi: 10.1016/S10432760(02)00666-5

Pabon, M. M. (2011). An Observation of Immunological Effect, A Diet Enhanced with Spirulina and Treatment with Fractalkine in Models of Parkinson's Disease. Graduate Theses and Dissertations, University of South Florida, Tampa, FL.
Pabon, M. M., Jernberg, J. N., Morganti, J., Contreras, J., Hudson, C. E., and Klein, R. L. (2012). A spirulina-enhanced diet provides neuroprotection in an $\alpha$-synuclein model of Parkinson's disease. PLoS One 7:e45256. doi: 10.1371/ journal.pone.0045256

Pankaj, P. P. (2015). Efficacy of Spirulina platensis in improvement of the reproductive performance and easing teratogenicity in hyperglycemic albino mice. Indian J. Pharmacol. 47:430. doi: 10.4103/0253-7613.161271

Passineau, M. J., Green, E. J., and Dietrich, W. D. (2001). Therapeutic effects of environmental enrichment on cognitive function and tissue integrity following severe traumatic brain injury in rats. Exp. Neurol. 168, 373-384. doi: 10.1006/ exnr.2000.7623

Patil, J., Matte, A., Mallard, C., and Sandberg, M. (2018). Spirulina diet to lactating mothers protects the antioxidant system and reduces inflammation in postnatal brain after systemic inflammation. Nutr. Neurosci. 21, 59-69. doi: 10.1080/ 1028415X.2016.1221496

Patro, I., Nagayach, A., Sinha, S., and Patro, N. (2016). "General physiology and pathophysiology of microglia during neuroinflammation," in Inflammation: The Common Link in Brain Pathologies, 1st Edn, eds N. Jana, A. Basu, and P. N. Tandon (Singapore: Springer), 17-42. doi: 10.1007/978-981-10-1711-7_2

Patro, N., Naik, A. A., and Patro, I. K. (2018). Developmental changes in oligodendrocyte genesis, myelination, and associated behavioral dysfunction in a rat model of intra-generational protein malnutrition. Mol. Neurobiol. doi: 10.1007/s12035-018-1065-1 [Epub ahead of print].

Patro, N., Sharma, A., Kariaya, K., and Patro, I. (2011). Spirulina platensis protects neurons via suppression of glial activation and peripheral sensitization leading to restoration of motor function in collagen-induced arthritic rats. Indian J. Exp. Biol. 49, 739-748.

Patro, N., Singh, K., and Patro, I. (2013). Differential microglial and astrocytic response to bacterial and viral infection in the developing hippocampus of neonatal rats. Indian J. Exp. Biol. 51, 606-614.

Peeling, A. N., and Smart, J. L. (1994). Review of literature showing that undernutrition affects the growth rate of all processes in the brain to the same extent. Metab. Brain Dis. 9, 33-42. doi: 10.1007/BF01996072

Pitkin, R. M. (2007). Folate and neural tube defects. Am. J. Clin. Nutr. 85, 285S-288S. doi: 10.1093/ajcn/85.1.285S

Prado, E. L., and Dewey, K. G. (2014). Nutrition and brain development in early life. Nutr. Rev. 72, 267-284. doi: 10.1111/nure.12102

Rana, S., Pal Sodhi, C., Mehta, S., Vaiphei, K., Katyal, R., Thakur, S., et al. (1996). Protein-energy malnutrition and oxidative injury in growing rats. Hum. Exp. Toxicol. 15, 810-814. doi: 0.1177/09603271960150 1003

Ranade, S. C., Nawaz, M. S., Rambtla, P. K., Rose, A. J., Gressens, P., and Mani, S. (2012). Early protein malnutrition disrupts cerebellar development and impairs motor coordination. Br. J. Nutr. 107, 1167-1175. doi: 10.1017/ S0007114511004119

Rao, R., and Georgieff, M. K. (2001). Neonatal iron nutrition. Semin. Fetal Neonat. 5, 425-435. doi: 10.1053/siny.2001.0063

Rasool, M., and Sabina, E. P. (2009). Appraisal of immunomodulatory potential of Spirulina fusiformis: an in vivo and in vitro study. J. Nat. Med. 63:169. doi: 10.1007/s11418-008-0308-2

Redmond, H. P., Leon, P., Lieberman, M. D., Hofmann, K., Shou, J., Reynolds, J. V., et al. (1991). Impaired macrophage function in severe proteinenergymalnutrition. Arch. Surg. 126, 192-196. doi: 10.1001/archsurg.1991. 01410260080011

Regnault, T. R. H., Friedman, J. E., Wilkening, R. B., Anthony, R. V., and Hay, W. W. Jr. (2005a). Fetoplacental transport and utilization of amino acids in IUGR- a review. Placenta 26, S52-S62. doi: 10.1016/j.placenta.2005. 01.003

Regnault, T. R. H., Marconi, A. M., Smith, C. H., Glazier, J. D., Novak, D. A., Sibley, C. P., et al. (2005b). Placental amino acid transport systems and fetal growth restriction-a workshop report. Placenta 26, S76-S80. doi: 10.1016/j.placenta. 2005.02.006

Rekiel, A., Wi^ecek, J., Batorska, M., and Kulisiewicz, J. (2014). Effect of sow prolificacy and nutrition on preand postnatal growth of progeny-a review. Ann. Anim. Sci. 14, 3-15. doi: 10.2478/aoas-2013-0060

Reyes-Castro, L. A., Padilla-Gomez, E., Parga-Martínez, N. J., Castro-Rodríguez, D. C., Quirarte, G. L., Díaz-Cintra, S., et al. (2018). Hippocampal mechanisms in impaired spatial learning and memory in male offspring of rats fed a 
low-protein isocaloric diet in pregnancy and/or lactation. Hippocampus 28 , 18-30. doi: 10.1002/hipo.22798

Reynolds, L. P., and Caton, J. S. (2012). Role of the pre-and post-natal environment in developmental programming of health and productivity. Mol. Cell. Endocrinol. 354, 54-59. doi: 10.1016/j.mce.2011.11.013

Reynolds, S., Lane, S. J., and Richards, L. (2010). Using animal models of enriched environments to inform research on sensory integration intervention for the rehabilitation of neurodevelopmental disorders. J. Neurodev. Disord. 2:120. doi: 10.1007/s11689-010-9053-4

Rieder, M. J. (1994). Prevention of neural tube defects with periconceptional folic acid. Clin. Perinatol. 21, 483-503. doi: 10.1159/000330776

Rkhzay-Jaf, J., O’Dowd, J. F., and Stocker, C. J. (2012). Maternal obesity and the fetal origins of the metabolic syndrome. Curr. Cardiovasc. Risk Rep. 6, 487-495. doi: $10.1007 / \mathrm{s} 12170-012-0257-\mathrm{x}$

Rodriguez, J. J., Terzieva, S., Olabarria, M., Lanza, R. G., and Verkhratsky, A. (2013). Enriched environment and physical activity reverse astrogliodegeneration in the hippocampus of $\mathrm{AD}$ transgenic mice. Cell Death Dis. 4:e678. doi: 10.1038/cddis.2013.194

Rodulfo, B. R. (1990). "Culture and utilization of freshwater algae as protein source," in Proceedings of the Culture and Use of Algae in Southeast Asia (Bangkok: SEAFDEC), 81-87.

Rosenfeld, A., and Weller, A. (2012). Behavioral effects of environmental enrichment during gestation in WKY and Wistar rats. Behav. Brain Res. 233, 245-255. doi: 10.1016/j.bbr.2012.05.006

Rubinsztein, D. C., Difiglia, M., Heintz, N., Nixon, R. A., Qin, Z. H., Ravikumar, B., et al. (2005). Autophagy and its possible roles in nervous system diseases, damage and repair. Autophagy 1, 11-22. doi: 10.4161/auto.1.1.1513

Sahin, S., Tasar, P. T., Simsek, H., Çicek, Z., Eskiizmirli, H., Aykar, F. S., et al. (2016). Prevalence of anemia and malnutrition and their association in elderly nursing home residents. Aging Clin. Exp. Res. 28, 857-862. doi: 10.1007/s40520-0150490-5

Salas, M., and Nieto, A. (1974). Effects of neonatal food deprivation on cortical spines and dendritic development of the rat. Brain Res. 73, 139-144. doi: 10. 1016/0006-8993(74)91012-9

Salazar, M., Chamorro, G. A., Salazar, S., and Steele, C. E. (1996). Effect of Spirulina maxima consumption on reproduction and peri-and postnatal development in rats. Food Chem. Toxicol. 34, 353-359. doi: 10.1016/0278-6915(96)00000-2

Sauerwein, R. W., Mulder, J. A., Mulder, L., Lowe, B., Peshu, N., Demacker, P. N., et al. (1997). Inflammatory mediators in children with protein-energy malnutrition. Am. J. Clin. Nutr. 65, 1534-1539. doi: 10.1093/ajen/65.5.1534

Sawada, M., and Carlson, J. C. (1987). Changes in superoxide radical and lipid peroxide formation in the brain, heart and liver during the lifetime of the rat. Mech. Ageing Dev. 41, 125-137. doi: 10.1016/0047-6374(87)90057-1

Say, L., Gülmezoglu, A. M., and Hofmeyr, G. J. (2003). Maternal nutrient supplementation for suspected impaired fetal growth. Cochrane Database Syst. Rev. 1:CD000148. doi: 10.1002/14651858.CD000148

Sederquist, B., Fernandez-Vojvodich, P., Zaman, F., and Savendahl, L. (2014). Recentresearch on the growth plate: impact of inflammatory cytokines on longitudinal bone growth. J. Mol. Endocrinol. 53, 35-44. doi: 10.1530/JME-140006

Selmi, C., Leung, P. S., Fischer, L., German, B., Yang, C. Y., Kenny, T. P., et al. (2011). The effects of Spirulina on anemia and immune function in senior citizens. Cell Mol. Immunol. 8:248. doi: 10.1038/cmi.2010.76

Sharma, M. K., Sharma, A., Kumar, A., and Kumar, M. (2007). Spirulina fusiformis provides protection against mercuric chloride induced oxidative stress in Swiss albino mice. Food Chem. Toxicol. 45, 2412-2419. doi: 10.1016/j.fct.2007.06.023

Shih, R. A., Belmonte, P. L., and Zandi, P. P. (2004). A review of the evidence from family, twin and adoption studies for a genetic contribution to adult psychiatric disorders. Int. Rev. Psychiatry 16, 260-283. doi: 10.1080/09540260400014401

Sieroszerski, P., Suzin, J., and Karowicz-Bilińska, A. (2004). Ultrasound evaluation of intrauterine growth restriction therapy by a nitric oxide donor (Larginine). J. Matern. Fetal Neonatal Med. 15, 363-366. doi: 10.1080/ 14767050410001725280

Sies, H. (1985). Oxidative stress: introductory remarks. Oxid. Stress 501, 1-8. doi: 10.1016/B978-0-12-642760-8.50005-3

Silva, S. V., Garcia-Souza, E. P., Moura, A. S., and Barja-Fidalgo, C. (2010). Maternal protein restriction during early lactation induces changes on neutrophil activation and TNF- $\alpha$ production of adult offspring. Inflammation 33, 65-75. doi: 10.1007/s10753-009-9159-6

Silveira, P. P., Portella, A. K., Goldani, M. Z., and Barbieri, M. A. (2007). Developmental origins of health and disease (DOHaD). J. Pediatr. 83, 494-504. doi: 10.2223/JPED. 1728

Simpore, J., Kabore, F., Zongo, F., Dansou, D., Bere, A., Pignatelli, S., et al. (2006). Nutrition rehabilitation of undernourished children utilizing Spiruline and Misola. Nutr. J. 5:3. doi: 10.1186/1475-2891-5-3

Simpore, J., Zongo, F., Kabore, F., Dansou, D., Bere, A., Nikiema, J. B., et al. (2005). Nutrition rehabilitation of HIV-infected and HIV-negative undernourished children utilizing spirulina. Ann. Nutr. Metab. 49, 373-380. doi: 10.1159/ 000088889

Simpson, J., and Kelly, J. P. (2011). The impact of environmental enrichment in laboratory rats- behavioural and neurochemical aspects. Behav. Brain Res. 222, 246-264. doi: 10.1016/j.bbr.2011.04.002

Sive, A. A., Subotzky, E. F., Malan, H., Dempster, W. S., De, V., and Heese, H. (1993). Red blood cell antioxidant enzyme concentrations in kwashiorkor and marasmus. Ann. Trop. Paediatr. 13, 33-38. doi: 10.1080/02724936.1993. 11747622

Smart, J. L., Dobbing, J., Adlard, B. P. F., Lynch, A., and Sands, J. (1973). Vulnerability of developing brain: relative effects of growth restriction during the fetal and suckling periods on behavior and brain composition of adult rats. Int. J. Nutr. 103, 1327-1338. doi: 10.1093/jn/103.9.1327

Sohal, R. S., and Dubey, A. (1994). Mitochondrial oxidative damage, hydrogen peroxide release, and aging. Free Radic. Biol. Med. 16, 621-626. doi: 10.1016/ 0891-5849(94)90062-0

Solomons, N. W. (2007). Malnutrition and infection: an update. Br. J. Nutr. 98, S5-S10. doi: $10.1017 /$ S0007114507832879

Spring, P. C. M., Amancio, O. M. S., Nobriga, F., Araujo, G., Koppel, S. M., and Dodge, J. A. (1985). Fat and energy content of breast milk of malnourished and well nourished women, Brazil 1982. Ann. Trop. Paediatr. 5, 83-87. doi: 10.1080/02724936.1985.11748368

Stromberg, I., Gemma, C., Vila, J., and Bickford, P. C. (2005). Blueberry-and spirulina-enriched diets enhance striatal dopamine recovery and induce a rapid, transient microglia activation after injury of the rat nigrostriatal dopamine system. Exp. Neurol. 196, 298-307. doi: 10.1016/j.expneurol.2005.08.013

Tranquille, N., Emeis, J. J., De Chambure, D., Binot, R., and Tamponnet, C. (1994). Spirulina acceptability trials in rats. A study for the "Melissa" life-support system. Adv. Space Res. 14, 167-170. doi: 10.1016/0273-1177(94)90293-3

Valko, M., Leibfritz, D., Moncol, J., Cronin, M. T., Mazur, M., and Telser, J. (2007). Free radicals and antioxidants in normal physiological functions and human disease. Int. J. Biochem. Cell Biol. 39, 44-84. doi: 10.1016/j.biocel.2006.07.001

Vega, C. C., Reyes-Castro, L. A., Rodríguez-Gonzalez, G. L., Bautista, C. J., Vazquez-Martinez, M., Larrea, F., et al. (2016). Resveratrol partially prevents oxidative stress and metabolic dysfunction in pregnant rats fed a low protein diet and their offspring. J. Physiol. 594, 1483-1499. doi: 10.1113/JP271543

Verma, A., Saini, T., and Meena, K. (2017). Evaluation of oxidative stress in severe acute malnourished children at malnutrition treatment centre of Sardar Patel Medical College, Bikaner, Rajasthan, India. Int. J. Res. Med. Sci. 4, 2259-2261. doi: $10.18203 / 2320-6012$. ijrms20161796

Voltarelli, F. A., and de Mello, M. A. R. (2008). Spirulina enhanced the skeletal muscle protein in growing rats. Eur. J. Nutr. 47, 393-400. doi: 10.1007/s00394008-0740-9

Von Grebmer, K., Bernstein, J., Hammond, L., Patterson, F., Sonntag, A., Klaus, L., et al. (2018). 2018 Global Hunger Index: Forced Migration and Hunger. Bonn: Welthungerhilfe and Concern Worldwide.

Wang, Y., Chang, C. F., Chou, J., Chen, H. L., Deng, X., and Harvey, B. K. (2005). Dietary supplementation with blueberries, spinach, or spirulina reduces ischemic brain damage. Exp. Neurol. 193, 75-84. doi: 10.1016/j.expneurol.2004. 12.014

Watanabe, F., Takenaka, S., Kittaka-Katsura, H., Ebara, S., and Miyamoto, E. (2002). Characterization and bioavailability of vitamin B12-compounds from edible algae. J. Nutr. Sci. Vitaminol. 48, 325-331. doi: 10.3177/jnsv. 48.325

Welsh, F. K. S., Farmery, S. M., MacLennan, K., Sheridan, M. B., Barclay, G. R. and Guillou, P. J. (1998). Gut barrier function in malnourished patients. Gut 42, 396-401. doi: 10.1136/gut.42.3.396 
West, C. D., and Kemper, T. L. (1976). The effect of a low protein diet on the anatomical development of the rat brain. Brain Res. 107, 221-237. doi: 10.1016/ 0006-8993(76)90223-7

Woodward, B. (1998). Protein, calories, and immune defenses. Nutr. Rev. 56, S84-S92. doi: 10.1111/j.1753-4887.1998.tb01649.x

Wu, G., Bazer, F. W., Cudd, T. A., Meininger, C. J., and Spencer, T. E. (2004). Maternal nutrition and fetal development. J. Nutr. 134, 2169-2172. doi: 10. 1093/jn/134.9.2169

Wu, G., Bazer, F. W., Wallace, J. M., and Spencer, T. E. (2006). Board-invited review: intrauterine growth retardation: implications for the animal sciences. J. Anim. Sci. 84, 2316-2337. doi: 10.2527/jas.2006-156

Wu, G., Imhoff-Kunsch, B., and Girard, A. W. (2012). Biological mechanisms for nutritional regulation of maternal health and fetal development. Paediatr. Perinat. Epidemiol. 26, 4-26. doi: 10.1111/j.1365-3016.2012.01291.x

Wu, Q., Liu, L., Miron, A., Klímová, B., Wan, D., and Kuca, K. (2016). The antioxidant, immunomodulatory, and anti-inflammatory activities of Spirulina: an overview. Arch. Toxicol. 90, 1817-1840. doi: 10.1007/s00204-0161744-5

Wu, Z., Yu, J., Zhu, A., and Nakanishi, H. (2016). Nutrients, microglia aging, and brain aging. Oxid. Med. Cell Longev. 2016:7498528. doi: 10.1155/2016/7498528
Xiao, X. M., and Li, L. P. (2005). Arginine treatment for asymmetric fetal growth restriction. Int. J. Gynaecol. Obstet. 88, 15-18. doi: 10.1016/j.ijgo.2004.09.017

Yamada, S., Tokumoto, M., Tatsumoto, N., Tsuruya, K., Kitazono, T., and Ooboshi, H. (2016). Very low protein diet enhances inflammation, malnutrition, and vascular calcification in uremic rats. Life Sci. 146, 117-123. doi: 10.1016/j.lfs.2015.12.050

Yuan, Z. Y., Gu, P., Liu, L., Wang, Y. Y., Liu, J., and Cui, D. S. (2009). Neuroprotective effects of enriched environment in MPTP-treated SAMP8 mice. Neurosci. Lett. 454, 6-10. doi: 10.1016/j.neulet.2009.02.058

Conflict of Interest Statement: The authors declare that the research was conducted in the absence of any commercial or financial relationships that could be construed as a potential conflict of interest.

Copyright (c) 2018 Sinha, Patro and Patro. This is an open-access article distributed under the terms of the Creative Commons Attribution License (CC BY). The use, distribution or reproduction in other forums is permitted, provided the original author(s) and the copyright owner(s) are credited and that the original publication in this journal is cited, in accordance with accepted academic practice. No use, distribution or reproduction is permitted which does not comply with these terms. 